\title{
Polyploid Gene Expression and Regulation in Polysomic Polyploids
}

\author{
Pham Van Hieu ${ }^{1,2}$ (1) \\ ${ }^{1}$ Graduate School of Life and Environmental Sciences, University of Tsukuba, Tsukuba, Japan \\ ${ }^{2}$ Biotechnology Center of Ho Chi Minh City, Ho Chi Minh City, Vietnam \\ Email: hieupvbio@gmail.com
}

How to cite this paper: Hieu, P.V. (2019) Polyploid Gene Expression and Regulation in Polysomic Polyploids. American Journal of Plant Sciences, 10, 1409-1443. https://doi.org/10.4236/ajps.2019.108101

Received: July 13, 2019

Accepted: August 26, 2019

Published: August 29, 2019

Copyright (c) 2019 by author(s) and Scientific Research Publishing Inc. This work is licensed under the Creative Commons Attribution International License (CC BY 4.0).

http://creativecommons.org/licenses/by/4.0/

\begin{abstract}
Polyploidization is one of the most crucial pathways in introducing speciation and broadening biodiversity, especially in the Plant Kingdom. Although the majority of studies have focused only on allopolyploid or disomic polyploids, polysomic polyploid species have occurred frequently in higher plants. Due to the occurrence of the capabilities of more copies of alleles in a locus which can have additive dosage effects and/or allelic interactions, polysomic polyploids can lead to unique gene regulations to silence or adjust the expression level to create variations in organ size, metabolic products, and abiotic stress tolerance and biotic stress resistance, etc. This review aims to comprehensively summarize the contemporary understanding and findings concerning the molecular mechanisms of gene expression as well as gene regulation in natural typed and resynthesized polysomic polyploid plants. The review investigates the molecular level of phenomena in polysomic polyploid plants such as 1) typically enlarging organ size and stabilizing meiosis, 2) increasing phytochemical content and metabolic products, 3) enhancing the ability to adapt with biotic and abiotic stress, and 4) changing in gene regulation to silence or adjust the expression levels involve in sequence elimination, methylation, gene suppression, subfunctionalization, neo-functionalization, and transposon activation.
\end{abstract}

\section{Keywords}

Polysomic Polyploids, Allelic Interactions, Gene Expression and Regulation, Evolution

\section{Introduction}

A plentiful history and various approaches have been used to study polyploid. Over one hundred years, the early stage of cytological investigations has found 
phenomenon that some plants have had a set of doubled chromosomes [1]. Polyploid hypothesis has been suggested by Winge, 1917 [2]. Based on the origins of polyploids, polyploids have divided into autopolyploid and allopolyploid [3]. Autopolyploid plants double a set of chromosomes of the same species (Table 1); allopolyploid plants are coming together with various types of chromosomes which from different species. Origin of polyploids has resulted in non-reduced gametes and somatic doubling [4] [5] [6]. Based on the genetic or cytogenetic features of polyploids, polysomic polyploids are comprised of homologous chromosomes that segregate from multivalents or stochastic bivalents. On the other hand, disomic polyploids are comprised of at least two arrangements of homeologous chromosomes that segregate from bivalents shaped distinctly between homologous chromosomes [7]. Polysomic polyploid is utilized by Mackey (1970) [8], rather than "autopolyploid" as utilized by Stebbins (1947) [9] and other botanists. The term "polysomic polyploid" refers to autopolyploids with multiple copies of alleles in a locus and at least 2 paired homologous chromosomes in gametogenesis that form multivalents [8] [10] [11] [12]. Recently, there has been an increasing interest in the exploration of the polysomic polyploidy mechanism, leading to the re-emergence of concerns about polyploid plants [13]. Previous studies mainly unraveled a hypothesis that polysomic polyploids are evolutionary dead-ends [14] [15]. However, recent research in angiosperm plants revealed that autopolyploids occur more popular than expected and just as frequently as allopolyploids [16] [17]. Possibly due to genome rearrangements, polysomic polyploids have been proven to have a high level of hereditary and genomic diversity, leading to a variety of biochemical products [18] [19] [20]. Therefore, polyploids might have broader ecological amplitudes than their diploid counterparts; in consequence, polyploid events occur more frequently in domesticated plants than their wild relatives, e.g. $54 \%$ of monocot crops are polyploids, while $40 \%$ of them are wild species [20] [21]. However, wild relatives have potentially advantageous gene pools, determining biotic stress resistance and abiotic stress tolerance (in corn, cotton, rice, and soybean) [22] or attractive traits (in potatoes [23] [24]). Current strategies for domestication and breeding of wild relatives may reduce the hereditary diversity of all crops [25]. Therefore, the majority of commercial crops are polyploids, which have an increased level of heterozygosity, compared to diploids [26] Several crops are autopolyploidy plants (watermelon, strawberries, potato, banana, and alfalfa) derived from an increased allele number generating novel morphologies. Polyploidy, being so widespread crops must have some selective benefits such as hybrid vigors, enabling evolutions in the changing functions of genes, and alternation of regulation [27]. Polyploid have also been used as a bridging organism by constructing innovative cultivar species involving autotriploids (triploid sugar beet and watermelon), autotetraploid (potato, alfalfa) that have larger flowers and more extended blooming period [28]. One practical application of polyploid is an enhancement and expansion of commercial crops. 
Table 1. Chromosome number of diploid and polyploid plants.

\begin{tabular}{|c|c|c|c|}
\hline No. & Species & $\begin{array}{l}\text { Chromosome number of } \\
\text { diploid and polyploids }\end{array}$ & Reference \\
\hline 1 & Camellia sinensis $\mathrm{L}$. & $2 \mathrm{n}=2 \mathrm{x}=30,2 \mathrm{n}=4 \mathrm{x}=60$ & [71] \\
\hline 2 & Lycopersicum esculentum & $2 \mathrm{n}=2 \mathrm{x}=24,2 \mathrm{n}=4 \mathrm{x}=48$ & {$[134]$} \\
\hline 3 & Citrus limonia Osbeck & $2 \mathrm{n}=2 \mathrm{x}=18,2 \mathrm{n}=4 \mathrm{x}=36$ & {$[135]$} \\
\hline 4 & Arabidopsis thaliana & $2 \mathrm{n}=2 \mathrm{x}=10,2 \mathrm{n}=4 \mathrm{x}=20$ & [96] \\
\hline 5 & Biscutella laevigata & $2 \mathrm{n}=2 \mathrm{x}=18,2 \mathrm{n}=4 \mathrm{x}=36$ & {$[128]$} \\
\hline 6 & Brassica rapa & $2 \mathrm{n}=2 \mathrm{x}=20,2 \mathrm{n}=4 \mathrm{x}=40$ & [64] \\
\hline 7 & Paulownia tomentosa & $2 \mathrm{n}=2 \mathrm{x}=40,2 \mathrm{n}=4 \mathrm{x}=80$ & {$[136]$} \\
\hline 8 & Anoectochilus formosanus Hayata & $2 \mathrm{n}=2 \mathrm{x}=24,2 \mathrm{n}=4 \mathrm{x}=48$ & {$[40]$} \\
\hline 9 & Helianthus decapetalus & $\begin{array}{c}2 \mathrm{n}=2 \mathrm{x}=34,2 \mathrm{n}=4 \mathrm{x}=68 \\
2 \mathrm{n}=6 \mathrm{x}=102\end{array}$ & [137] \\
\hline 10 & Morus alba L. & $2 \mathrm{n}=2 \mathrm{x}=28,2 \mathrm{n}=4 \mathrm{x}=56$ & [57] \\
\hline 11 & Phlox drummondii Hooker & $2 \mathrm{n}=2 \mathrm{x}=14,2 \mathrm{n}=4 \mathrm{x}=28$ & {$[116]$} \\
\hline 12 & Nicotiana benthinana & $2 \mathrm{n}=4 \mathrm{x}=38,2 \mathrm{n}=8 \mathrm{x}=76$ & {$[138]$} \\
\hline 13 & Paulownia fortunei & $2 \mathrm{n}=2 \mathrm{x}=40,2 \mathrm{n}=4 \mathrm{x}=80$ & [139] \\
\hline 14 & Chrysanthemum nankingense & $2 \mathrm{n}=2 \mathrm{x}=18,2 \mathrm{n}=4 \mathrm{x}=36$ & {$[113]$} \\
\hline 15 & Citrullus lanatus & $\begin{array}{c}2 \mathrm{n}=2 \mathrm{x}=22,2 \mathrm{n}=3 \mathrm{x}=33 \\
2 \mathrm{n}=4 \mathrm{x}=44\end{array}$ & {$[140]$} \\
\hline 16 & Chrysanthemum lavandulifolium & $2 \mathrm{n}=2 \mathrm{x}=18,2 \mathrm{n}=4 \mathrm{x}=36$ & {$[106]$} \\
\hline 17 & Brassica rapa L. ssp. pekinensis & $\begin{array}{c}\mathrm{n}=\mathrm{x}=10,2 \mathrm{n}=2 \mathrm{x}=20 \\
2 \mathrm{n}=4 \mathrm{x}=40\end{array}$ & [64] \\
\hline 18 & Malus $\times$ domestica Borkh & $2 \mathrm{n}=2 \mathrm{x}=34,2 \mathrm{n}=4 \mathrm{x}=68$ & [58] \\
\hline 19 & Arabidopsis arenosa & $2 \mathrm{n}=2 \mathrm{x}=16,2 \mathrm{n}=4 \mathrm{x}=32$ & {$[141]$} \\
\hline 20 & Linum album & $2 \mathrm{n}=2 \mathrm{x}=18,2 \mathrm{n}=4 \mathrm{x}=36$ & {$[42]$} \\
\hline 21 & Oryza sativa & $2 \mathrm{n}=2 \mathrm{x}=24,2 \mathrm{n}=4 \mathrm{x}=48$ & {$[76]$} \\
\hline 22 & Hordeum bulbosum & $2 \mathrm{n}=2 \mathrm{x}=14,2 \mathrm{n}=4 \mathrm{x}=28$ & {$[50]$} \\
\hline 23 & Isatis indigotica & $2 \mathrm{n}=2 \mathrm{x}=14,2 \mathrm{n}=4 \mathrm{x}=28$ & {$[49]$} \\
\hline 24 & Paspalum notatum & $2 \mathrm{n}=2 \mathrm{x}=20,2 \mathrm{n}=4 \mathrm{x}=40$ & {$[47]$} \\
\hline 25 & Papaver somniferum $\mathrm{L}$ & $2 \mathrm{n}=2 \mathrm{x}=22,2 \mathrm{n}=4 \mathrm{x}=44$ & {$[43]$} \\
\hline 26 & Betula platyphylla & $2 \mathrm{n}=2 \mathrm{x}=28,2 \mathrm{n}=4 \mathrm{x}=56$ & {$[51]$} \\
\hline 27 & Paulownia australis & $2 \mathrm{n}=2 \mathrm{x}=40,2 \mathrm{n}=4 \mathrm{x}=80$ & {$[55]$} \\
\hline 28 & Physalis angulata LINN & $2 \mathrm{n}=2 \mathrm{x}=36,2 \mathrm{n}=4 \mathrm{x}=72$ & {$[84]$} \\
\hline 29 & Dendrocalamus latiflorus Munro & $\begin{array}{c}2 \mathrm{n}=3 \mathrm{x}=36,2 \mathrm{n}=6 \mathrm{x}=72 \\
2 \mathrm{n}=12 \mathrm{x}=144\end{array}$ & [119] \\
\hline 30 & Nicotiana alata & $2 \mathrm{n}=2 \mathrm{x}=18,2 \mathrm{n}=4 \mathrm{x}=36$ & [98] \\
\hline 31 & Solanum phureja & $\begin{array}{c}\mathrm{n}=\mathrm{x}=12,2 \mathrm{n}=2 \mathrm{x}=24 \\
2 \mathrm{n}=4 \mathrm{x}=48\end{array}$ & {$[108]$} \\
\hline 32 & Lonicera japonica Thunb. & $2 \mathrm{n}=2 \mathrm{x}=18,2 \mathrm{n}=4 \mathrm{x}=36$ & {$[91]$} \\
\hline 33 & Medicago sative L. & $2 \mathrm{n}=2 \mathrm{x}=16,2 \mathrm{n}=4 \mathrm{x}=32$ & {$[142]$} \\
\hline 34 & Dioscorea zingiberensis & $2 \mathrm{n}=2 \mathrm{x}=20,2 \mathrm{n}=4 \mathrm{x}=40$ & [97] \\
\hline 35 & Anacamptis pyramidalis & $2 \mathrm{n}=2 \mathrm{x}=36,2 \mathrm{n}=4 \mathrm{x}=72$ & {$[59]$} \\
\hline 36 & Centaurea phrygia & $2 \mathrm{n}=2 \mathrm{x}=22,2 \mathrm{n}=4 \mathrm{x}=44$ & {$[60]$} \\
\hline 37 & Pyrus communis & $2 \mathrm{n}=2 \mathrm{x}=34,2 \mathrm{n}=4 \mathrm{x}=68$ & [143] \\
\hline
\end{tabular}


Polyploidy is increasing in frequency in the plant kingdom as more evidence shows that nearly $70 \%$ of angiosperms have a historical evolution involving one or more periods of genetic materials duplication in their progenitors [29] [30]. Polyploid went through with short-term factors affecting survival such as effects on species interactions, environmental robustness, and biodiversity before facing long-term factors as environmental instability [31] [32] [33]. Paleopolyploids, a kind of ancient polyploid, as well as novel polyploids have remarkably changed their size, components, and intricate hereditary materials. Catalysts for processes of speciation and biodiversification might derive from preserved pivotal genes, changed functions, and alterations in complex regulatory systems after the enlargement of genomic potential through key innovations or phenotypic alternations [7] [34] [35] [36] [37]. Genetic material content and transcriptomes may rapidly change after polyploidization, and regulatory interactions occurred in levels of subgenomes [38].

Much research on gene expressions and transcriptomes has showed several divergences between ploidy levels of three kinds of plants, i.e., herbs, shrubs, and trees. Polysomic polyploid herbs have tended to upregulate genes related to the biosynthesis pathways [39] [40] [41] [42] [43] [44]. The differences of transcriptomes concerned functions in polarity of cell and conservation of cell membrane integrity, cell wall biogenesis, synthesized pectin, and metabolism [45] [46], cluster DNA repair process, chromosome structure modification, adjustment of transcriptomes, protein function in lysis, folding, metabolites of carbohydrates and lipids [47], signal transductions, transcriptional regulations, metabolic pathways and developmental pathways [48] [49], synthesis of expansin and pectin (cell development), cell wall elements, metabolic processes of byproducts, and the pathways of responsive adverse condition and using light energy pathways, antioxidant enzymes, more express miR528-3p in DNA-replication, repair, and salinity stress. Additional, miRNAs also play an important role in function in polysomic polyploid to support a high concentration of salt tolerance [50]. In trees, gene expression and transcriptomes found genes linked to biosynthesis, leading to change in transduction pathways and ethylene after polysomic polyploid resulting in morphological changes [51], as well as pivotal differential expression belong to carbon fixation group and energy metabolism group [52], photosynthesis, the synthesis of lignin, and the enhancement of manifested transcription factors in tetraploid supporting salt tolerance [53]. Transcriptomes in trees also revealed several miRNAs that play a role in drought stress [54] [55] [56]. Besides, shrubs showed divergent photosynthesis processes and the promotion of biosynthesis as well as adjusted phytohormone pathways including auxin, gibberellins, cytokinin, and ethylene [57], increased the proline content and expression of aquaporin genes [58].

Polysomic polyploid changes development processes involved in periods of flowering, grain production. The autotetraploid Anacamptis pyramidalis shifted its flowering time and enhanced a new environmental adaptation that persisted in the subsequent population differences in diploid [59]. A study seed produc- 
tion of the autotetraploid and its diploid Centaurea phrygia showed greater seed production in higher ploidy [60]. The analysis of a whole genome of the Arabidopsis arenosa autotetraploid and its diploid counterpart showed that several genes related to genome conservation functions were a hereditary adaptation after polyploidization consisting of chromosomal cohesion and separation, DNA reparation, crossover, modulation of transcription and framing of genetic materials. It anticipated to gene interaction with each other's [61]. Polysomic polyploid has confirmed the need to continue studying novel functional genes. Changes in gene functions might occur following polyploidization as a case of neofunctionalization [62] [63].

The purpose of this review not only is to concisely evaluate the latest progress of polysomic polyploid but also summarize the current state of this phenomenon. It creates an understanding of polysomic polyploid by discussing the findings presented in recent research papers. This review paper also presents some challenges. In general, the studies on polysomic polyploid are scarce. The difference in transcriptomes of polysomic polyploid is not as obvious as in allopolyploid. In cases of whole genome duplication, transcriptome analysis becomes complicated due to massive data and several complicated processes involved along with elucidating the complicated physiological, cytological and molecular mechanism. This review aim to consolidate understanding of the molecular characteristics of genetics of polysomic polyploids based on recent research related to some native attributes of natural-typed and resynthesized autopolyploid plants, e.g. larger organs, meiosis stability, high concentrations of phytochemicals and metabolic products, adaptive responses to biotic and abiotic stresses, the molecular mechanisms of gene expression as well as gene regulation (sequence elimination, methylation, gene suppression, subfunctionalization, neo-functionalization, and transposon activation) are also concerned.

\section{Polysomic Polyploids Have a Phenotypic Meiotic Peculiarity}

Polysomic polyploids are prevalently known as organisms whose enlarged organs are constructed by mechanisms of extension and divarication at the cell levels. In one study, a series of ploidy of Chinese cabbage (Brassica rapa L. ssp. pekinensis) originating from a haploid plant showed an enhanced ARGOS expression in proportional polysomic levels in both leaves and floral bud [64] [65]. In addition, overexpression of ARGOS protein is thought to regulate downstream of transcription factor ANT (AITEGUMENTA) in promoting cell division of aerial organs through modulating cyclin CYCD3, a factor involving in a cell cycle. Besides, the increase of ARGO signals may boost the expression of Arabidopsis Growth-Regulating Factor 1 (AtGRF1) and Arabidopsis EXPASIN 10 (AtEXPA10) that regulate cell expansion [66]. In another study, transcription of the lipid transport genes such as $w b c 11-2$ and cer5-2 was found to enhance cell extension of hypocotyls in polyploidy thale cress grown in the dark. Both of those genes were further discovered to have an important role in the genesis of a 
thicker cuticular layer of tetraploid mouse-ear cress [67] [68] [69]. Another recent study also showed changes in a cell wall composition and plant growth after polyploidization occurred [70]. In general, size enlargement in polysomic polyploid plants is promoted by both cell proliferation and cell length consequently leading to gigantic effects [64] [71]. Enlarged organ size in a polysomic polyploid plant usually leads to increased yield and crop production [71]. As mentioned earlier, enlarged organs are quite common in polysomic polyploidy. However, in some cases like the tetrasomic tetraploid apple tree (Malus domestica), a dwarf morphology was unexpectedly found compared to its diploid counterpart. A test of the paraffin diploid sample showed that the vertical parenchyma cell was longer than in higher ploidy. The third and fifth year of autotetraploid apples showed a sharp reduction in phytohormone concentration of indoleacetic acid (IAA) and brassinosteroid (BR). Digital gene expression (DGE) for RNA-seq also revealed divergent transcriptions related to IAA and BR networks. A microarray result additionally showed that enhanced microRNA390 in duplicated genotype could led to upregulation of MdTAS3 (apple trans-acting short-interfering RNA3), which might downregulate $M d A R F 3$. This molecular mechanism interrupted the activation pathway of IAA and BR, which afterward lead to the midget phenotype of tetrasomic tetraploid apples [72]. Biosynthesis and signal transduction of IAA (indole acetic acid) and ethylene were found modified after genotype duplication in Betula platyphylla, which subsequently developed morphological changes [51].

In polyploid plants, phenotypic and microstructural variation occurred in phenomena that related to expression level in transcriptome analysis. In a study on polysomic polyploid Paulownia australis, larger and broader polyploid leaves that were found to have larger but fewer cells than diploid ones could possibly be an evidence of phenotypic and microstructural variation of ploidies. Likewise, Rangpur lime (Citrus limonia) autotetraploid showed remarkable differences in the structure and physiology of leaves, stems, and roots comparing to diploids. Interestingly, these physiological changes were not parallel to the corresponding modification that occurred in foliar transcription. Microarray analysis on leaf transcriptome on 21,081 genes revealed that there were less than $1 \%$ differences in gene expression, with a maximum of twofold differnce in expression level between diploid and tetraploid. Furthermore RT-PCR confirmed microarray results for six of those upregulated genes: five genes function in drought stress and act the same way in both ploidy levels, the last one codes a histone which might play a pivotal role in modulating development [73]. Transcriptome analysis in another study of Betula platyphylla autotetraploid showed direct link between upregulated 7052 unigenes and downregulated 3658 unigenes and the alteration morphologies [51]. Aside from transcriptomes studies, proteomes research on Paulownia australis detected 773 differentially abundant proteins (DAPs) out of total 3010 proteins that might be involved in cell proliferation, synthesis of glutathione and the constituents of the cell wall (lignin, cellulose) and photosynthetic pigments [74]. Analysing proteomes plays a pivotal role in identification 
protein conferring functions that are differentially abundant protein in cell proliferation.

After autopolyploidization, polysomic polyploid meiosis became more intricate due to the occurrence of multivalents. The disjuncture of sister chromosomes in gametogenesis needs to be equal to make microspores [75]. Using microarray dissection to evaluate the hereditary deviation of male gametogenesis, researchers found that diploid and tetrasomic tetraploid rice displayed several unusual chromosome manners, involving multivalents, cell proliferation lacked asynchronous, chromosomes that lagged, etc. in gametogenesis of higher ploidy. Although the higher ploidy rice exhibited several divergent types of irregularity such as multi-aperture, the degeneracy of male gametophytes, and difference of cell wall, the generation of microspores and microgametes the two types of ploidy rice were nearly the same. The maintained expression of genes supported pollen growth as well as cell metabolism, cell physiology, binding, catalytic process, molecular transducer process and regulatory pathways of transcription. In ambrosia transcriptome of polyploid rice was 1251 genes were expressed differentially than in diploid with 1011 upregulated transcripts and 240 down-regulated ones. The number of 124 co-up-regulated transcripts and six co-down-regulated ones have identified for the time of three phases of pollen generation-almost genes connected to pollen growth up-regulated in polyploid rice. In doubled tetraploid rice, differential expressions of some pivotal genes affected the complex gene modulation with the abnormal creation of male gametophytes [76]. Thus, a comparison of diploid and autotetraploid thale cress Arabidopsis arenosa by SNP analyzing revealed 70 genes linked to gametogenesis. Choosing seven genes encoding structural proteins (ASY1, ASY3 PDS5, ZYP1a, ZYP1b, SMC1, and SYN1/AtREC8) that are associated with meiosis, pre-prophase containing sister chromosome cohesion, axis formation, and crossing over. There was a divergent transcription of these genes in two kinds of ploidy Arabidopsis [77]. The divergence of genetic modulation in floral bud development at the meiosis of diploid and its tetraploid Brassica rapa identified by comparing RNA profiles showed 4601 DEGs (differentially expression genes), 288 of which are functional in meiosis, including $D M C 1$ genes identified as having a function in repairing DNA double-stranded breaks (DSBs) and being meiosis gene [78]. This gene was downregulated in tetrasomic tetraploid B. rapa, which supports the explanation of anomalous meiosis I. In addition, DEGs with functions on enzymes for a form of RNA molecules, somatic DNA repair, and cell-division cycle were up-regulated in tetraploid genomic plant [79]. Remarkably, an investigation of the differently expressed miRNAs (DEM) in a period of growth of male gametes and female gametophytes of seeds plant in tetrasomic tetraploid rice revealed 321 and 368 DEM, respectively. It had seven dominance classes of gene function involving sequence-specific DNA binding factors and flora progress allied to pollen growth and 30 dominance classes of gene function consisting of transduction cues and specialized cell types to promote the growth of embryo sac in tetraploid rice. In 39 DEM interacting with genes connected to meiosis that were examined, a level 
of expression unraveled the differential expression in growing male gametes and embryo sac. Osa-miR167h-3p and osa-miR1436_L + 3_1ss5CT supported to female gametogenesis and osa-miR159a.1 and osa-MIR159a-p5 connected to the pollen formation. 24nt-phasiRNAs only related to pollen growth while 21nt-phasiRNAs promoted all pollens and embryo sacs that showed reduced expression in tetrasomic tetraploid collated to diploid rice, and osa-miR2275d presented the same pattern of space-time expression. It was found that $24 \mathrm{nt}$ Tes-siRNAs enhanced in megagametophytes and repressed in a male gamete growth [80].

\section{Polysomic Polyploid Plants Can Increase Phytochemical Content and Metabolic Products}

Polysomic polyploid plants have changed in phytochemical content and metabolites are showed in Table 2. A recent study of the tetrasomic tetraploid opium poppy (Papaver somniferum L.) inducing $0.25 \%$ and $0.40 \%$ colchicine enhanced the expression of many genes belonging to the alkaloid biosynthesis pathways such as tyrosine/dopa decarboxylase (TYDC), (S)-N methylcoclaurine-3'-hydroxylase (CYPB80B1), codeinine reductase (COR), (S) norcoclaurine-6-O-methyltransferase (6OMT), (S)-3'-hydroxy-N-methylcoclaurine-4'-O methyl-transferase (4'OMT), reticuline 7-O-methyl transferase (7OMT), (S)-coclaurine N-methyltransferase (CNMT), 7(S)-salutaridinol 7-O-acetyltransferase (SALAT), major latex protein (MLP) and salutaridinol 7-O-acetyltransferase (SAT) genes to increase morphine content $25 \%-50 \%$ [43]. Remarkably, concetration of lycopene in watermelon dependent on ploidy levels [81] [82]. A study of the divergent lycopene substances and phytohormones in a series of ploidy watermelons (diploid, autotriploid and autotetraploid) revealed that lycopene synthesis was controlled by phytohormone and level of genes expression involved. Particularly, gibberellin (GA) accretion and lycopene components had a negative link in all ploidy levels of fruit. Only in low ploidy watermelon, abscisic acid (ABA) gathering supported high lycopene content. Lycopene content in diploid watermelon was less than in two kinds of higher ploidy [41] [81]. It was heterosis lycopene, hybrid vigor between diploid and tetraploid made more lycopene in autotriploid throughout the fruit growth and ripened phase. Genes related to biosynthesis lycopene phytoene synthase (PSY1), phytoene desaturase (PDS), $\zeta$-carotene desaturase (ZDS), carotenoid isomerase (CRTISO), and lycopene $\beta$-cyclase (LCYB) in autotriploid and autotetraploid plants had a high expression than lower ploidy ones [41].

Dissection carried out in autotetraploid Linum album (family Linaceae) induced by colchicine showed an increased concentration of podophyllotoxin (PTOX) caused by changes in podophyllotoxin biosynthetic pathways. Some of the upregulated genes with functions involved in the processing of PTOX biosynthesis were PAL (phenylalanine ammonia-lyase), CCR (cinnamoyl CoA reductase), CAD (cinnamyl-alcohol dehydrogenase) and PLR (pinoresinol-lariciresinol reductase) in autotetraploid plant [42]. In a previous study on autotetraploid 
Table 2. Polysomic polyploid leads to change in phytochemical and metabolites.

\begin{tabular}{|c|c|c|c|c|}
\hline Scientific name & Ploidy & $\begin{array}{l}\text { Phytochemical and } \\
\text { metabolite products }\end{array}$ & The mechanism molecular & Ref. \\
\hline Papaver somniferum $\mathrm{L}$. & $\begin{array}{c}\text { Diploid and } \\
\text { autotetraploid }\end{array}$ & $\begin{array}{l}\text { Increase morphine } \\
25 \%-50 \% \text {. }\end{array}$ & $\begin{array}{l}\text { Enhance many genes expression belongs to alkaloid } \\
\text { biosynthesis pathway }\end{array}$ & [43] \\
\hline Citrullus lanatus & $\begin{array}{l}\text { Diploid, autotriploid } \\
\text { and autotetraploid }\end{array}$ & $\begin{array}{l}\text { Increase lycopene } \\
\text { contents }\end{array}$ & $\begin{array}{l}\text { Biosynthesis lycopene phytoene synthase, phytoene } \\
\text { desaturase } \zeta \text {-carotene desaturase, carotenoid isomerase, } \\
\text { and lycopene } \beta \text {-cyclase more expression }\end{array}$ & [41] \\
\hline Linum album & $\begin{array}{l}\text { Diploid and } \\
\text { autotetraploid }\end{array}$ & $\begin{array}{l}\text { Increase podophyllotoxin } \\
\text { (PTOX) }\end{array}$ & $\begin{array}{l}\text { Upregulated genes related to pathway of PTOX biosyn- } \\
\text { thesis }\end{array}$ & [42] \\
\hline $\begin{array}{l}\text { Lycopersicum } \\
\text { esculentum }\end{array}$ & $\begin{array}{l}\text { Diploid and } \\
\text { autotetraploid }\end{array}$ & Higher protein & $\begin{array}{l}\text { Upregulation genes malate dehydrogenase, acid inver- } \\
\text { tase, glutamate dehydrogenase, and nitrate reductase }\end{array}$ & [39] \\
\hline $\begin{array}{l}\text { Arabidopsis } \\
\text { Thaliana Col-0 }\end{array}$ & $\begin{array}{l}\text { Diploid and } \\
\text { autotetraploid }\end{array}$ & $\begin{array}{l}\text { Change metabolite of TCA } \\
\text { and GABA }\end{array}$ & $\begin{array}{l}\text { Genes related to TCA (tricarboxylic acid cycle) and } \\
\text { GABA ( } \gamma \text {-aminobutyric acid) divergent expression }\end{array}$ & [83] \\
\hline $\begin{array}{l}\text { Anoectochilus } \\
\text { formosanus Hayata }\end{array}$ & $\begin{array}{l}\text { Diploid and } \\
\text { autotetraploid }\end{array}$ & $\begin{array}{l}\text { Increase total flavonoid and } \\
\text { gastrodin }\end{array}$ & Enhanced the tropane biosynthetic pathways & [40] \\
\hline Citrullus lanatus & $\begin{array}{l}\text { Diploid and } \\
\text { autotetraploid }\end{array}$ & Change in gene expression & $\begin{array}{l}\text { Some upregulated genes in tetrasomic tetraploid were } \\
\text { Arginine biosynthesis, chlorophyllide synthesis, GDP } \\
\text { mannose biosynthesis, trehalose biosynthesis, and starch } \\
\text { and sucrose degradation pathways }\end{array}$ & [44] \\
\hline Paulownia fortunei & $\begin{array}{l}\text { Diploid and } \\
\text { autotetraploid }\end{array}$ & Change in gene expression & $\begin{array}{l}\text { Showed } 6.09 \% \text { pivotal differential expression belong to } \\
\text { carbon fixation group and energy metabolism group }\end{array}$ & [85] \\
\hline Morus alba L. & $\begin{array}{l}\text { Diploid and } \\
\text { autotetraploid }\end{array}$ & Change in gene expression & $\begin{array}{l}\text { Showed } 2.87 \% \text { (609) genes that changed the level of gene } \\
\text { expression in total 21,229 expressed genes, } 30 \text { genes were } \\
\text { promoting the biosynthesis and transduction cues of } \\
\text { phytohormones such as cytokinin, gibberellins, ethylene, } \\
\text { and auxin }\end{array}$ & [57] \\
\hline Arabidopsis thaliana & $\begin{array}{l}\text { Diploid and } \\
\text { autotetraploid }\end{array}$ & Change gene expression & $\begin{array}{l}92 \text { homeologous gene pairs that were differential } \\
\text { expression at tissue-specific as aerial tissue and apical } \\
\text { tissue with function in cell polarity and conservation of } \\
\text { cell wall integrity for development and stress tolerance }\end{array}$ & [45] \\
\hline Paspalum notatum & $\begin{array}{l}\text { Diploid and } \\
\text { autotetraploid }\end{array}$ & Change gene expression & $\begin{array}{l}26 \text { divergent genes having a function and } 22 \text { novel } \\
\text { sequences }\end{array}$ & [47] \\
\hline Tolmiea & $\begin{array}{c}\text { Diploid and } \\
\text { autotetraploid }\end{array}$ & Change gene expression & $\begin{array}{l}17 \% \text { differential gene expression comparing between } \\
\text { tetraploid and diploid plant }\end{array}$ & [86] \\
\hline Isatis indigotica & $\begin{array}{l}\text { Diploid and } \\
\text { autotetraploid }\end{array}$ & Change gene expression & $\begin{array}{l}4.3 \% \text { differential gene expression, signal transduction, } \\
\text { transcriptional regulation, metabolic and developmental } \\
\text { pathway }\end{array}$ & [49] \\
\hline Paulownia tomentosa & $\begin{array}{l}\text { Diploid and } \\
\text { autotetraploid }\end{array}$ & Change gene expression & $\begin{array}{l}\text { Differentially expressed unigenes related to pathways } \\
\text { such as } 30 \text { photosynthesis response, } 21 \text { transcription } \\
\text { factors, and } 22 \text { lignin process }\end{array}$ & [87] \\
\hline Isatis indigotica Fort & $\begin{array}{l}\text { Diploid, autotetraploid, } \\
\text { autotetraploid }\end{array}$ & Change gene expression & $\begin{array}{l}\text { Differentially expressed genes were significantly in } \\
\text { expansin and pectin synthesis (cell growth), cell wall } \\
\text { components, secondary metabolic pathways, and the } \\
\text { pathway of the stress response and photosynthesis }\end{array}$ & [46] \\
\hline $\begin{array}{l}\text { Solanum commersonii } \\
\text { and Solanum } \\
\text { bulbocastanum }\end{array}$ & $\begin{array}{l}\text { Diploid and } \\
\text { autotetraploid }\end{array}$ & Change in gene expression & $\begin{array}{l}\text { Pericentromeric regions more enriched differentially } \\
\text { expression genes }\end{array}$ & [88] \\
\hline
\end{tabular}


made from diploid Lycopersicum esculentum, the level of gene expression changed with the gene dosage. The results showed upregulation in some genes activity of malate dehydrogenase, acid invertase, glutamate dehydrogenase, and nitrate reductase and decreased peroxidase activity; but it did not change the polymorphism of the listed enzymes [39]. Thus, applying the nuclear magnetic resonance (NMR) method, quantitative real-time PCR (qRT-PCR) and elemental analysis (carbon: nitrogen balance) to study the divergence between diploids and autotetraploids Arabidopsis thaliana Col-0 showed that metabolites belonged to TCA (tricarboxylic acid cycle) and GABA ( $\gamma$-amino butyric acid) shunt concentrated, glutamate and GABA are linked to the TCA cycle through a short pathway composed of three enzymes called the GABA shunt, due to bypassing two steps of the TCA cycle. The genes related to the TCA and GABA were divergently expressed between ploidy levels (diploids and autotetraploids) following the level of corresponding metabolites [83]. In addition, resynthesized autotetraploid Anoectochilus formosanus Hayata made by inducing colchicine showed that compared to its progenitor diploid the tetraploid produced expressively more contents of total flavonoid and gastrodin in the leaf, the stem, and the whole plant [40]. Recently work in using the system of gas chromatography to investigate some kinds of fatty acid containing in diploid $(\mathrm{n}=12)$ and tetraploid ( $\mathrm{n}=24)$ of Physalis angutala Linn. from Rajasthan revealed variable percentages of palmitic acid $(6.966 \%, 2 x ; 12.38 \%, 4 x)$; linoleic acid $(5.5 \%, 2 x ; 9.76 \%$, $4 \mathrm{x})$ and linolenic acid $(6 \%, 2 \mathrm{x} ; 11.67 \%, 4 \mathrm{x})$ [84].

High throughput technologies involving microarray or RNA-seq technology might support the detailed study of transcriptome and polysomic polyploids to determine the different levels of genes expressions. For example, a comparison of transcriptomes between autotetraploid and diploid watermelon using RNA-seq found 5362 upregulated genes and 1288 downregulated genes. Notably, it was recognized in leaf, stem, and fruits with 22 genes that caused alternative splicing, showing abilities of a making the difference of isoforms of protein changed roles of pivotal both carriers and sequence-specific DNA-binding factors. Some upregulated genes in tetrasomic tetraploids were in involved in making of arginine, a precursor of chlorophyll, GDP mannose, trehalose, and starch and sucrose breakdown pathways [44]. Thus, analysis revealed a $6.09 \%$ variance of transcription profiles among Paulownia fortunei autotetraploid and its diploid progenitor (1158 transcriptions out of a total 18,984 transcripts) with pivotal expression difference belonging to the carbon fixation group and energy metabolism groups [85]. Likewise, the transcriptome profile of autotetraploid Mulberry (Morus alba L.) and its diploid showed $2.87 \%$ (609) genes that changed the rank of transcription out of a total 21,229 transcripts whereby forty-one genes belonging to photosynthesis changed their rate of expression along with thirty genes related to making phytohormones and their cues transduction such as auxin, ethylene, cytokinin, and gibberellins [57]. Examination of the Thale cress Arabidopsis thaliana showed variant gene expression after autopolyploidization. A set of 92 homeologous gene pairs showed tissue-specific subfunctionalization in aerial and 
apical tissues. The gene expression alterations were responsible for cell polarity and conservation of cell membrane integrity, cell wall biogenesis, and metabolism, as xyloglucan endotransglycosylase. In addition, several genes segregate roles through subfunctionalization, genes detached function, in development and stress tolerance [45]. A transcriptional profile of 10,000 genes in flowers of diploid and its autotetraploid Paspalum notatum showed 42 homologous genes to 26 divergent genes having a function and 22 novel structures. The roles of genes were in cluster DNA repair pathway, modifying the form of chromatin, adjustment of gene expression, protein function in lysis, folding, metabolite of carbohydrate and lipid, and transduction cues [47].

Studying the level of gene expression in diploid Tolmiea (Saxifragaceae) and its autotetraploid revealed the difference of biomass, the cell, and the whole transcriptome. Particularly, a divergent expression between tetraploid and diploid plant at cell level of 3005 upregulated and 751 downregulated genes were found, as well as 1440 and 1550 up-and down-regulated genes, respectively at the biomass level and 1559 up-and 1071 down-regulated genes at transcriptome level, amounting to about $17 \%$ differential gene expression between tetraploid and diploid plant [86]. A comparison of the RNA profile of tetraploid and its diploid Isatis indigotica revealed a $4.3 \%$ differential gene expression (715 upregulated genes and 251 downregulated genes in total 22,810 genes of a microarray of the Thale cress Arabidopsis thaliana Affymetrix Genechips). Up-regulated genes were largely signal communication, transcriptional adjustment, metabolic pathway and developmental pathway [49]. High-throughput sequencing methods used to study gene expression in the diploid and autotetraploid Paulownia tomentosa showed 2677 unigenes were significantly divergently expressed in tetraploid. Differentially expressed unigenes related to pathways such as 30 photosynthesis response, 21 transcription factors and 22 lignin process were found. The functions of peroxidase in biosynthetic lignin, MYB DNA-binding proteins, and WRKY proteins related to modulating the relevant hormones [87].

Investigation of a series of polyploid Chinese woad plant (Isatis indigotica Fort)-diploid, triploid and tetraploid-utilizing RNA sequencing discovered the variation of transcripts containing up and down. The DEGs (differentially expressed genes) concerned the production of expansin and pectin with a role in the growth of a cell, cell wall constituents, networks of secondary metabolites, the processes coping to adverse conditions and the synthesis of phytochemicals with the aid of radiant energy. In higher polyploid, enhanced DEGs connected metabolic synthesis of functional chemicals [46]. An inspection of the total number of metabolites and transcriptome profile between wild diploid and its doubled tetraploid Solanum commersonii and Solanum bulbocastanum showed more enhanced DEGs in pericentromeric regions. The numbers of alternations were random; it has a robustly responsively genotypes. Adenine, guanine, and nucleosides were typical controlled transcripts and metabolites due to popular response to genome duplication [88]. A study of Arabidopsis thaliana, and Pyrus communis var. sativa autopolyploids revealed that hyperaccumulation of meta- 
bolites derived from the result of minor natural selection [89]. A comparison of metabolome profiles of diploid and wild and non-natural $A$. thaliana autotetraploid showed the difference of these profiles. The metabolomes of wild autotetraploid interrelated to their environmental origin. The different profiles may support the idea that plant acclimate to the antagonistic ecological condition [90].

\section{Polysomic Polyploid Can Enhance the Ability to Adapt to Abiotic and Biotic Stress}

Adapting to harsh environmental conditions is one of the major challenges of plants. Table 3 displays a list of polysomic polyploidy plants have the ability to abiotic tolerance stresses and biotic resistant stresses. An investigation of photosynthesis proportion and carboxylation effectiveness of diploid and tetraploid Honeysuckle (Lonicera japonica Thunb.) under saline pressure $(300 \mathrm{mM} \mathrm{NaCl})$ showed that both ploidies decreased. However, diploid was more decreasing. The tetraploid conserved well the relation among PSII and PSI to avoid photoinhibition and showed better photosynthetic action compared to diploid under effect of salt. Thus, tetraploid honeysuckle had less ionic poisonousness because of further $\mathrm{Na}+$ extrusion in root and more $\mathrm{Na}+$ moving to leaf to support the ability of photosynthesis [91]. Similar results were reported in salinity pressure of $150 \mathrm{mM} \mathrm{NaCl}$ applied at 3 and 5 days to inspect root tolerance among two rice sorting diploid rice (HN2026-2x and Nipponbare-2x), and autotetraploid one (HN2026-4x and Nipponbare-4x) showed lesser root growth hindrance and more proline accretion in autotetraploid rice, but a smaller amount of MDA. Moreover, increasing proton carriage into the apical root and decreasing $\mathrm{Na}+$ influx into the root improved root adaptation to salt effects [85]. Likewise, an examination of the response to salt of diploid and autotetraploid turnip (Brassica rapa L.) at 5-7 leaf stage showed a better tolerance among high ploidy plant. There were substantial changes of gene expression belonging to the group of antioxidant enzymes, e.g., ascorbate peroxidase (APX), catalase (CAT), peroxidase (POD), superoxide dismutase (SOD), and glutathione reductase (GR). This group of genes mitigated the ROS (reactive oxygen species) collecting that damaged plants [92].

Recently, an interesting report analyzing transcriptome profiles on doubled genome Paulownia tomentosa and its diploid affected by salt showed reticulum and tree-pathogen interaction. Twenty unigenes were applied to a real-time PCR to approve the transcription. This insight into the hereditary foundation of salty pressure in Paulownia tomentosa supports plant breeding as well as the development of areas for Paulownia planting [87]. Thus, investigating transcriptomes among diploid and its doubled tetraploid Paulownia tomentosa under salt stress and annotating the divergent transcription using KEGG (Kyoto Encyclopedia of Genes and Genomes database) and together with use of GO (Gene Ontology) showed genes controlling the photosynthetic system and phytohormone cues transduction were pivotal for high salt adaptation. In particular, they were 
Table 3. Polysomic polyploid effects on abiotic and biotic stress.

\begin{tabular}{|c|c|c|c|c|}
\hline Scientific name & Ploidy & Tolerance & The ways to resistance & Ref. \\
\hline Lonicera japonica Thunb & $\begin{array}{c}\text { Diploid \& } \\
\text { autotetraploid }\end{array}$ & Salt stress & $\begin{array}{l}\text { Tetraploid more } \mathrm{Na}+\text { extrusion in root and higher } \mathrm{Na}+ \\
\text { transport to leaf, supporting photosynthesis }\end{array}$ & [91] \\
\hline $\begin{array}{l}\text { Oryza sativa } \\
\text { Nipponbare }\end{array}$ & $\begin{array}{c}\text { Diploid \& } \\
\text { autotetraploid }\end{array}$ & Salt stress & $\begin{array}{l}\text { Tetraploid more proline, less MDA, increasing proton } \\
\text { transport and decreasing } \mathrm{Na}+\text { influx into the root }\end{array}$ & [85] \\
\hline Brassica rapa L. & $\begin{array}{c}\text { Diploid \& } \\
\text { autotetraploid }\end{array}$ & Salt stress & $\begin{array}{l}\text { Tetraploid increasing gene expression of antioxidant APX, } \\
\text { CAT, POD, SOD, and GR; mitigating ROS }\end{array}$ & [92] \\
\hline Paulownia tomentosa & $\begin{array}{l}\text { Diploid \& } \\
\text { autotetraploid }\end{array}$ & Salt stress & $\begin{array}{l}\text { RNA transporter, phytohormone transduction cues, protein } \\
\text { processing, photosynthesize cues, AP2/EREBP, MYB, NAC, } \\
\text { and bHLH }\end{array}$ & [53] [133] \\
\hline Medicago sativa $\mathrm{L}$. & $\begin{array}{c}\text { Diploid \& } \\
\text { autotetraploid }\end{array}$ & Salt stress & $\begin{array}{l}36 \text { SNP markers related to salt stress, } 14 \text { genes functionalized to } \\
\text { abiotic stress related to } 23 \text { pivotal markers promote salt } \\
\text { tolerance }\end{array}$ & [93] \\
\hline Malus domestica & $\begin{array}{l}\text { Diploid \& } \\
\text { autotetraploid }\end{array}$ & Salt stress & $\begin{array}{l}\text { The expression of aquaporin gene (MdPIP1; } 1 \text { and MdTIP1; 1) } \\
\text { higher in tetraploid }\end{array}$ & [58] \\
\hline Hordeumbulbosum & $\begin{array}{c}\text { Diploid \& } \\
\text { autotetraploid }\end{array}$ & Salt stress & $\begin{array}{l}\text { miRNAs support tolerance salt stress. e.g. miR528-3p was } \\
\text { function in DNA-replication, repair }\end{array}$ & [50] \\
\hline Paulownia fortune & $\begin{array}{c}\text { Diploid \& } \\
\text { autotetraploid }\end{array}$ & Salt stress & $\begin{array}{l}\text { Increasing of soluble sugars, up-regulated ATP synthase to } \\
\text { enhance ion transport changing proton } 8 \text { miRNAs more } \\
\text { enhanced and } 10 \text { new miRNAs }\end{array}$ & [95] [102] \\
\hline $\begin{array}{l}\text { P. australis; } \\
\text { P. fortunei; } \\
\text { P. tomentosa; }\end{array}$ & $\begin{array}{l}\text { Diploid \& } \\
\text { autotetraploid }\end{array}$ & Drought stress & $\begin{array}{l}\text { miRNAs and target genes related to transcriptional regulation, } \\
\text { hormone metabolism, and plant defense }\end{array}$ & $\begin{array}{c}{[54]} \\
{[55][56]}\end{array}$ \\
\hline Dioscorea zingiberensis & $\begin{array}{c}\text { Diploid \& } \\
\text { autotetraploid }\end{array}$ & Heat stress & $\begin{array}{l}\text { Activation of the antioxidant defense system and enhanced } \\
\text { heat tolerance compared to diploid plant }\end{array}$ & [97] \\
\hline Nicotiana benthamiana & Tetraploid \& octaploid & Cold stress & Increasing antioxidant (SOD, CAT, APX...) & [105] \\
\hline Arabidopsis thaliana & $\begin{array}{l}\text { Diploid \& } \\
\text { autotetraploid }\end{array}$ & Copper stress & $\begin{array}{l}\mathrm{Cu} \text { transport gene, AtHMA5, AtCOX17, and AtMT2b, } \\
\text { activation of antioxidative defense, positive regulation of } \\
\text { expression ABA-responsive genes }\end{array}$ & [96] \\
\hline $\begin{array}{c}\text { Citrus sinensis } \mathrm{L} . \\
\text { Poncirustrifoliata L. }\end{array}$ & $\begin{array}{c}\text { Diploid \& } \\
\text { autotetraploid }\end{array}$ & Boron stress & The root anatomical characters of the $4 \mathrm{x}$ plants & [100] \\
\hline Betula platyphylla & $\begin{array}{c}\text { Diploid \& } \\
\text { autotetraploid }\end{array}$ & $\mathrm{NaHCO}_{3}$ stress & $\begin{array}{l}\text { Enhancing the expression of some genes related to proline } \\
\text { biosynthesis in tetraploid }\end{array}$ & [98] \\
\hline Malus $\times$ domestica Borkh & $\begin{array}{c}\text { Diploid \& } \\
\text { autotetraploid }\end{array}$ & $\begin{array}{l}\text { Resistance of } \\
\text { Venturia }\end{array}$ & Containing Rvi6 resistance gene-locus significantly increased & [105] \\
\hline
\end{tabular}

several sequence-specific DNA-binding elements such as a group of AP2/EREBP, MYB, NAC, and bHLH [53].

Surprisingly, the researchers found that 36SNP markers related to salt stress in germination were located in all chromosomes, not chromosome 3. Chromosome 1,2 and 4 contained quite a lot of pivotal markers in autotetraploid alfalfa $(\mathrm{Me}$ dicago sativa L.) as found by the use of genotyping-by-sequencing. This study identified 14 genes functionalized to abiotic stress related to 23 pivotal markers that promote salt tolerance in germination [93]. Thus, an investigation the difference under increased salt conditions between diploid and tetrasomic tetrap- 
loid apple at $200 \mathrm{mmol} / \mathrm{l} \mathrm{NaCl}$ for eight days displayed an ability to adapt well to salt pressure in the tetraploid plant. In the tetraploid apple, the relative water content (RWC) increased compared to its counterpart under saltier conditions. However, the proline as well as the concentration of malondialdehyde (MDA) was augmented in the diploid, but less in the autotetraploid plant. The transcripts of genes coding water channels (MdPIP1; 1 and MdTIP1; 1) in diploid was less than in the autotetraploid at all sampling times and at $24 \mathrm{~h}$ was decreased 4 - to 10 -fold. Due to higher expressed levels of these genes, the autotetraploid had a better tolerance than diploid under salt stress [58]. Likewise, the tetraploid Arabidopsis increased the concentration of $\mathrm{K}$ uptake to support enhancing salt resistance compared to its diploid [94]. Moreover, genome doubling affected miRNAs expression in diploid and tetraploid check Hordeum bulbosum under salt stress, five miRNAs in particular (miR171i, miR479, miR5048, mir6196 and miR528b-3p). One of these, miR528-3p was only found in the doubling genomic plant and repressed under salt stress. The result showed that miR528-3p has a function in DNA-replication, repair and salt stress. Additionally, miRNAs played role in autopolyploid to support tolerance of salt stress [50]. A study of the alteration of miRNAs under salt stress among the diploid Paulownia fortunei and its polysomic polyploid identified 53 conservated miRNAs in 17 miRNA groups and 134 new miRNAs in the species. A comparison of gene expression between ploidy levels of $P$. fortunei under high salt concentration revealed eight miRNAs that are more enhanced in the tetraploid than in the diploid from ten preserved and ten new miRNAs [95].

Autotetraploid mouse-ear cress was more tolerant to copper comparing with the diploid plant due to the enriched activation of antioxidative protection pathways, the change in the expression of genes supporting $\mathrm{Cu}$ carriage and chelation, and the promotion of control of transcript for ABA-responsive genes. The diploid Arabidopsis accumulated more Cu, ROS, and MDA compared with tetraploid plants. The tetraploid enhanced expression of AtHMA5, AtCOX17, and AtMT2b which help with tolerance to copper [96]. A Dioscorea zingiberensis autotetraploid induced by $0.15 \%$ colchicine for $24 \mathrm{~h}$ gained more antioxidant protection and improved heat tolerance compared to the diploid. At high heat $\left(42^{\circ} \mathrm{C}\right)$ for five days, the autotetraploid yam retained higher concentrations of vitamin $\mathrm{C}$, glutathione (GSH), and a biocatalytic substance that inhibits oxidation consisting of ascorbate peroxidase, the reduction of $\mathrm{H}_{2} \mathrm{O}_{2}$, the oxidation of a particular substrate by $\mathrm{H}_{2} \mathrm{O}_{2}$, superoxide dismutase, and $\mathrm{GSH}$ reductase. Aditionally, in a tetrasomic tetraploid herd were less cell damage and concentration of MDA, superoxide anions and $\mathrm{H}_{2} \mathrm{O}_{2}$ than in diploid ones [97]. A comparison of Betula platyphylla diploid and its tetraploid plant in $\mathrm{NaHCO}_{3}$ stress revealed that the proline content of the higher ploidy plant was higher due to enhanced expression of some gene related to proline biosynthesis such as $B P P 5 C S 1$, $B p P 5 C S 2, B p P 5 C R 1, B P P 5 C R 2, B p P 5 C R 3$, and BpOAT. In a diploid plant, $B p P r o D H$ and $B p P 5 C D H$ was less expression compared with tetraploid trees [98]. An examination of the diploid and its autotetraploid Nicotiana alata 
showed mineral contents ( $\mathrm{N}$ and $\mathrm{P}$ ) in higher ploidy plants differed [99]. Tetraploid Citrus sinensis L. Osb. $\times$ Poncirus trifoliata L. Raf increased its boron tolerance due to change in the anatomical root structure [100]. A comparative proteomic between diploid and autotetraploid Paulownia tomentosa by isobaric tag for relative and absolute quantitation coupled with liquid chromatography-tandem mass spectrometry detected a total of 1427 proteins with 130 proteins were divergently expression of ploidy level. Functional dissection of divergently expression proteins showed an enhancement of proteins related to photosynthesis and related to responsive stress to support increasing photosynthesis and stress adaptability in the tetraploid $P$. tomentosa. Additionally, this study showed $11.5 \%$ of transcriptome and proteome relationship between diploid and tetraploid [101]. An analysis of proteins alternation in the leaf of diploid and doubled tetraploid Paulownia fortunei by iTRAQ dissection distinguished 2634 proteins, 152 of which were specific DAPs related to autotetraploid. It was functional with $26 \mathrm{GO}$ functional groups and 22 KEGG metabolic processes. The enhanced sugar carrier associated to the intensification of soluble sugars that fluctuate the osmotic compression and the up-regulated ATP synthase delta in ATP led to an enhancement of the ion transport that changes proton rate to react to salt stress [102]. An inspection of the gap in the expression of diploid and autotetraploid thale cress in water deficit and regulator condition showed a changed expression of 441 upregulated genes and 30 downregulated genes in polyploidy plant compared to lower ploidy in 471 total genes (normal condition) and 977 up-regulated genes and 383 down-regulated genes of polysomic polyploid related to diploid Arabidopsis [103].

A study of microRNAs among doubled tetraploid Paulownia australis and its diploid under water deficit condition at $25 \%$ and $75 \%$ of relative soil moisture content identified four small RNA molecule (sRNA) archives and the same number of degradome ones. A total of 33 preserved and 104 new microRNAs were identified, along with 125 aim units of genetic for 36 of the microRNAs by applying the degradome fragments of which 54 and 68 expressed divergently in diploid and higher ploidy trees under water deficit condition (25\%). The function of almost microRNAs and aim transcripts were linked to growth and react to environmental stress [55]. A study of doubled tetraploid Paulownia fortunei (Seem) Hemsl and its diploid coping with drought pressure discovered 258 transcripts and 11 microRNAs correlated to genes that responded to shortage of water and microRNAs in this tree. Additionally, degradome sequencing uncovered 28 microRNA target genes linked to 9 preserved miRNA classes and 12 new miRNAs [56]. Profiling of microRNAs on tetrasomic tetraploid Paulownia tomentosa and its diploid counterpart under a lack of water showed pivotal divergent expression of microRNAs: in the autotetraploid 53 microRNAs with six preserved and 47 novels and in another plant 67 microRNAs with 26 preserved and 41 novels. Additionally, 356 candidate microRNAs were discovered by degradome analysis that target transcripts connected to transcriptional adjustment, phytohormone metabolism and plant protection. In detail, only in the higher 
ploidy plant under shortage of water were miR4 and miR156 induced [54]. In the octaploid tobacco plant (Nicotiana benthamiana) polysomic polyploid plants enhance cold stress by increasing antioxidant (SOD, CAT, APX...) compared to tetraploid [104]. Additionally, the polysomic polyploid had enhanced biotic resistant. The neotetraploid apple (Malus $\times$ domestica Borkh.) induced by colchicine from diploid apple containing Rvi6 resistance gene-locus significantly increased the ability to resist to Venturia inaequalis after artificial infection and checked by visual symptom analysis and real-time PCR [105].

\section{Polysomic Polyploid Species Have Changed Gene Regulation to Silence or Adjust Expression Level (such as Sequence Elimination, Cytosine Methylation, Gene Repression, Neofunctionalization, Subfunctionalization, and Transposon Activation)}

Polysomic polyploid plants altered gene expression and gene regulation is summarized in Table 4. Genome doubling in autotetraploid Chrysanthemum lavandulifolium (Fisch. ex Trautv.) Makino resulted in $1.1 \%$ lost fragments and $1.6 \%$ new fragments compared with its diploid plants. The altered genome was analyzed by sequence-related amplified polymorphisms (SRAP) [106]. A wide-ranging investigation sequenced 20 flowering plants to elucidate the presence of duplication-resistance genes showed many genes returned to singletons after polyploidization. This may be explained by stochastic gene loss under the selection pressure of singletons [107]. A cDNA microarray with 9000 transcripts to analyze the transcriptome of a series of potato ploidy involving haploid, diploid and tetrasomic tetraploid showed $10 \%$ genes that deviations expression belongs to ploidies in both foliage and root tips. In those cluster of genes in leaf, enhanced expression related to DNA binding and fundamental molecule action (the molecular function) and the cytoplasmic matrix and ribosome (the frame constituent ontologies) [108]. About 25,500 methylated transcripts gained from analyzing the methylation in a conjunction with gene expression and small RNA in a divergence of rice ploidy level. An inspection of the methyl group added to a unique gene showed 22,751 genes added to the methyl groups presented in all three lines, monoploid, diploid and triploid. A comparison of each pair of ploidies, showed that 64 transcripts exhibited a pivotal dissimilar DNA methylation. Additionally, sequencing small RNA profiles detected 36 novel microRNAs with a divergent level of expression connected to ploidy level [109]. Previously, a study of methylation profiles of diploid and its polysomic polyploid rice unraveled methylated class II of transposable fundamentals that impact gene expression [110]. Cytosine methylation of genome-scale led to a large plant size and enhanced phytochemical in autotetraploid Cymbopogon compared to diploid [111]. If DNA methylated occurs in transcription factors, it might change in the expression of other genes. An examination of silencing and innovative transcriptions in diploid, autotetraploid, and autohexaploid heredities of Helianthus decapetalus showed that autopolyploidy does not induce silencing or new gene 
Table 4. Alternation of gene regulation and adjust expression level.

\begin{tabular}{|c|c|c|c|c|}
\hline Species & Ploidy & Alternation & Methods and change in polysomic polyploid & Ref. \\
\hline $\begin{array}{l}\text { Chrysanthemum } \\
\text { lavandulifolium }\end{array}$ & $\begin{array}{l}\text { Diploid and } \\
\text { autotetraploid }\end{array}$ & $\begin{array}{l}\text { Genes loss and new } \mathrm{f} \\
\text { ragments appearance }\end{array}$ & $\begin{array}{l}\text { Sequence-related amplified polymorphisms (SRAP), made } \\
1.1 \% \text { lost fragments and } 1.6 \% \text { new fragment appeared }\end{array}$ & [106] \\
\hline 20 flowering plants & Autotetraploid & Gene loss & $\begin{array}{l}\text { Random gene loss under the selection pressure of } \\
\text { singletons }\end{array}$ & [107] \\
\hline Solanum sp. & $\begin{array}{l}\text { Haploid, diploid and } \\
\text { autotetraploid }\end{array}$ & $\begin{array}{l}\text { Change in gene } \\
\text { expression }\end{array}$ & $\begin{array}{l}\text { cDNA microarray } 9000 \text { genes showed } 10 \% \text { genes that change } \\
\text { expression belong to ploidies in both foliage and root tips }\end{array}$ & [108] \\
\hline Rice & $\begin{array}{l}\text { Monoploid, diploid, } \\
\text { triploid }\end{array}$ & $\begin{array}{l}\text { Methylation, gene } \\
\text { expression, and small RNA }\end{array}$ & $\begin{array}{l}\text { About } 25,500 \text { genes investigated methylation of a single gene } \\
\text { with } 22,751 \text { methylated genes presented in all monoploid, } \\
\text { diploid and triploid rice. When comparing each pair of ploidy } \\
64 \text { genes that were pivotal different DNA methylation, } \\
\text { sequencing small RNA profiles detected } 36 \text { novel miRNAs } \\
\text { divergent level of expression related to ploidy level }\end{array}$ & [109] \\
\hline Rice & $\begin{array}{c}\text { Diploid and } \\
\text { Autotetraploid }\end{array}$ & Methylation & $\begin{array}{l}\text { Methylated class II of transposable elements that influence } \\
\text { gene expression }\end{array}$ & [110] \\
\hline Cymbopogon & $\begin{array}{l}\text { Diploid and } \\
\text { Autotetraploid }\end{array}$ & Cytosine methylation & $\begin{array}{l}\text { Cytosine methylation of genome-wide made large body size } \\
\text { and enhance phytochemical in autotetraploid }\end{array}$ & [111] \\
\hline Helianthus decapetalus & $\begin{array}{l}\text { Diploid, Autotetraploid, } \\
\text { autohexaploid }\end{array}$ & Gene expression & $\begin{array}{l}\text { Populations of a single species can diverse in gene } \\
\text { expression patterns }\end{array}$ & [112] \\
\hline $\begin{array}{l}\text { Chrysanthemum } \\
\text { nankingense }\end{array}$ & $\begin{array}{c}\text { Diploid and } \\
\text { autotetraploid }\end{array}$ & miRNAs & $\begin{array}{l}\text { The rapid growth and development of autotetraploid were } \\
\text { promoted by a lot of target genes repressed by miRNAs }\end{array}$ & [113] \\
\hline Brassica rapa & $\begin{array}{c}\text { Diploid and } \\
\text { autotetraploid }\end{array}$ & $\begin{array}{l}\text { Methylation and DNA } \\
\text { fragment change }\end{array}$ & $\begin{array}{l}\text { Nearly } 0.58 \% \text { of changed fragments when using cDNA-AFLP } \\
\text { methods, DNA methylation changes about } 1.7 \% \text { of fragments } \\
\text { by using MSAP }\end{array}$ & [114] \\
\hline Malus $\times$ domestica Borkh & $\begin{array}{c}\text { Diploid and } \\
\text { autotetraploid }\end{array}$ & $\begin{array}{l}\text { Methylation, the effect of } \\
\text { ploidy in some gene } \\
\text { expression }\end{array}$ & $\begin{array}{l}\text { Similar between the two ploidy levels ( } 28.0 \% \text { vs } 27.3 \% \text { ) with the } \\
\text { frequency of methylated restriction sites, no discernible effect } \\
\text { on ploidy in the expression of MET1, DRM2, CTM }\end{array}$ & [115] \\
\hline $\begin{array}{l}\text { Phlox drummondii } \\
\text { Hooker }\end{array}$ & $\begin{array}{l}\text { The difference between } \\
\text { generations of } \\
\text { autopolyploid } \\
\left(\mathrm{C}_{0}, \mathrm{C}_{1}, \mathrm{C}_{2} \text {, and } \mathrm{C}_{3}\right)\end{array}$ & Polymorphism & $\begin{array}{l}\text { Polymorphism autotetraploid } \mathrm{C}_{0}, \mathrm{C}_{1}, \mathrm{C}_{2} \text { and } \mathrm{C}_{3} \text { were } 2.8 \% \text {, } \\
1.6 \%, 2.1 \% \text { and } 3.2 \% \text {, respectively by using RAPD }\end{array}$ & [116] \\
\hline Arabidopsis thaliana & $\begin{array}{l}\text { Diploid, autotriploid, } \\
\text { autotetraploid }\end{array}$ & $\begin{array}{l}\text { Loss and gain of DNA } \\
\text { sequence }\end{array}$ & $\begin{array}{l}\text { Loss and gain of DNA sequences of the first generation of } \\
\text { autopolyploid (short term "revolutionary alteration") while the } \\
\text { long term "revolutionary alteration" was a little change... }\end{array}$ & [117] \\
\hline Arabidopsis & Ploidy & Cis-regulatory elements & $\begin{array}{l}\text { Cis-regulatory elements showed the extensive difference in } \\
\text { regulatory elements and networks }\end{array}$ & [118] \\
\hline Isatisindigotica & Diploid and tetraploid & IiCPK2 expression & $\begin{array}{l}\text { Root, stem, and leaf of the tetraploid plant were more } \\
\text { expressions than diploid plant }\end{array}$ & {$[48]$} \\
\hline $\begin{array}{l}\text { Dendrocalamus } \\
\text { latiflorus Munro }\end{array}$ & $\begin{array}{l}\text { Triploid, hexaploid, } \\
\text { dodecaploid }\end{array}$ & $\begin{array}{l}\text { Differential expression } \\
\text { gene, } E X P B 3 \text {, and } T C P\end{array}$ & $\begin{array}{l}8396 \text { differential expression genes that belong to cell growth } \\
\text { and differentiation groups promoting growth and } \\
\text { development, EXPB3 and } T C P \text { related to cell proliferation } \\
\text { and differentiation }\end{array}$ & [119] \\
\hline Arabidopsis thaliana & Autotetraploid & Multivalent & Having translocation of $45 \mathrm{~S}$ gene between chromosome 3 and 4 & [120] \\
\hline Orchardgrass & Autotetraploid & $\begin{array}{l}\text { Inducing tetraploid by } \\
\text { colchicine }\end{array}$ & $\begin{array}{l}\text { Colchicine inhibited genes associated with microtubule, } \\
\text { spindle, chromosomal kinetochore, vesicle, cellulose and } \\
\text { pathways of cytoplasm movement, chromatid separation, } \\
\text { membrane, and cell wall development }\end{array}$ & [129] \\
\hline
\end{tabular}


expression. The results also showed that populations of a single species can differ in gene expression patterns. All the changes in gene expression in this report were found among populations [112].

The autotetraploid Chrysanthemum nankingense was vigor to half dose genetic plant due to the influence of some miRNAs. An investigation of the functions of the components of the miRNA of a diploid and its autotetraploid revealed 162 and 161 miRNA categorizations in diploid and tetrasomic tetraploid, respectively. The autotetraploid was the domination of miRNA with the size of 21 and 24 nucleotides, but 22 and 25 nucleotides were major miRNA in diploid. This study also displayed the rapid consequence of miRNAs. Several objective genes repressed by miRNAs promoted the rapid growth and development of higher ploidy. The great abundance of the miRNAs in both of ploidy was significant changed and augmented to their diversity [113]. Applying an AFLP (amplified fragment length polymorphism) to detect hereditary changes of autotetraploid Brassica rapa and its diploid counterpart showed no difference of ploidy. The autotetraploid Brassica rapa showed nearly $0.58 \%$ of changed fragments when a cDNA-AFLP method is applied. The MSAP (methylation-sensitive amplification polymorphism) method revealed that DNA methylation altered about $1.7 \%$ of sequences after doubling the whole genome and the same affected in hypermethylation and demethylation alternative [114]. Using a methylation-sensitive amplification polymorphism (MSAP) method to assess the level and pattern of DNA methylation of two ploidy apples showed a very similar result for the diploid apple cultivar and its autotetraploid (28.0\% vs $27.3 \%)$ with the rate of methylated restriction sites. The global level of DNA methylation had a low effect, but in the tetraploid, the frequency of patterns of hemimethylated sites increased. Comparing the level of expression of three genes modulated DNA methyltransferase exposed the lowest expression was MET1 the plant, while in the leaf, flower and fruit expression of DRM2 was expressed more, and CTM3 was high expression in the fruit. The transcription level of the three transcripts was no discernible effect on ploidy [115]. It has changed in the genome of diploid and its autopolyploid Phlox drummondii Hooker when comparing the difference of generations of autopolyploid $\left(\mathrm{C}_{0}, \mathrm{C}_{1}, \mathrm{C}_{2}\right.$, and $\mathrm{C}_{3}$ ). Polymorphism in the autotetraploid $\mathrm{C}_{0}, \mathrm{C}_{1}, \mathrm{C}_{2}$ and $\mathrm{C}_{3}$ were found to be 2.8, 1.6, 2.1 and 3.2\%, respectively using RAPD [116]. Using AFLP (amplified fragment length polymorphism) fingerprinting to analyse variation of genomic DNA polymorphism between diploid and its autopolyploid (autotriploid and autotetraploid) Arabidopsis thaliana revealed a rapid alteration in genome such as loss and gain of DNA fragments of the primary generation of autopolyploid (short term "revolutionary alteration") while the long term "revolutionary alteration" was only slight variations. This alternation in DNA fragment carried out in both exon and intron regions. Gene expression affected by autopolyploids led to changes such as deregulation, upregulation, and silencing such that after polyploidization there was an increase in heritable variation [117]. Using a high-throughput method to research on a single-base firmness of 
the cis-regulatory factors showed an extensive difference in controlling elements and systems between Arabidopsis ploidy in other organ types and developmental stages [118]. Comparing IiCPK2 expression among autotetraploid and diploid Isatis indigotica showed that the root, stem, and leaf of a tetraploid plant had more expressions than the diploid plant [48]. An investigation of the gene expression of polysomic polyploid of triploid $(2 \mathrm{n}=2 \mathrm{x}=36)$, hexaploid $(2 \mathrm{n}=6 \mathrm{x}=$ 72 ) and dodecaploid $(2 \mathrm{n}=12 \mathrm{x}=144)$ Ma bamboo (Dendrocalamus latiflorus Munro) discovered 8396 differential expression genes that belong to cell growth and differentiation groups promoting the development of a plant, of which EXPB3 and TCP were two common genes for significant modulated function in cell production and differentiation. Those genes linked to a network of coexpression with 222 genes [119]. Using FISH to double-target 45S and 5S rDNA sequences as makers showed autotetraploid thale cress Arabidopsis thaliana having a multivalent formation in gametogenesis and having a change of location of $45 \mathrm{~S}$ gene among chromosome 3 and 4 [120].

One of the changes following whole genome replication is subfunctionalization, in which couples of genes exercise a subset of their original inherited role. For example, $Z A G 1$ and $Z M M 2$ were from the ancestral AGAMOUS gene function in maize, functioning for male and female multiplicative organ growth as well as for flowery determinacy, the MADS-box family. Two paralogs had overlapping functions, but not identical activities [121]. Thus, a study of the evolutionary and functional mitochondrial GrpE (Mge) protein in mouse-ear cress Arabidopsis thaliana revealed AtMgel and AtMge2 derived from a whole genome duplication. However, ultraviolet B light-induced AtMgel; heat-induced AtMge2. After doubling and subfunctionalization, the individually allele of the Arabidopsis Mge transcript converted specifically in a different type. This was direct evidence that was associated with the relationship between gene doubling and acclimatization to environmental stress [122]. In addition, studying wild potato the line CMM1T of wild S. commersonii (PI243503) and "Blondy", "Désirée" and "Double Fun", the commercial potatoes, identified that replication of $R 2 R 3 M Y B$ transcripts caused by consequent subfunctionalization, $A N 1$ focused on making anthocyanin while $A N 2$ preserved the function to react to cold stress [123]. Another change after whole genome doubling was neofunctionalization as Arabidopsis containing a channel protein, the double copies of OEP16 gene that consists of OEP16-L and OEP16-S derived from duplication. AtOEP16-S containing numerous G-box ABA-responsive elements (ABREs) located in the promoter area. This copy is controlled by ABI3 and ABI5 and sharply expressed throughout the maturing stage in grains and pollen both dehydration adaptation in organs, while AtOEP-L without promoter ABREs, expressed mainly in leaves, induced strongly by cold stress and weakly in response to osmotic pressure, salicylic acid and exogenic abscisic acid [124]. Alteration of a MIKC-type, MADS protein domain, a crucial regulator of floret growth in higher plants and a change in expression form supported a new gene role in a rather short period. It was a remarkable the molecular levels of neofunctionali- 
zation after duplication. The thale cress Arabidopsis thaliana B-sister gene ABS (also known as TT16), was a function in the regulation of endothelium growth and synthesized anthocyanidin. GOA controlled fruit size via cell expansion [125].

In tetrasomic tetraploid involves four alleles in a locus, several circumstances can occur. Firstly, it might have further genotypes. For instance, with a diallelic locus, $\mathrm{B}$ and $\mathrm{b}$, five kinds of genotypes are possible such as $\mathrm{BBBB}, \mathrm{BBBb}, \mathrm{BBb}$, $B b b b$, and bbbb. In the case of additive effect, quantitative segregation might occur. Secondly, a greater diversity of numerous alleles can occur, with divergent function in the individual allele. Thirdly, these dissimilar alleles can interact. Several kinds of allelic interaction such as diallelic, triallelic and tetra-allelic lead to heterosis from an interaction between two alleles as well as various possibilities. Additive doge effect or allelic interaction combining with unique gene regulations to silence or adjust the expression level may cause tetrasomic tetraploid plant containing phenotype variation and variance of gene expression level compared to its counterpart diploid. The changes in hereditary tetrasomic tetraploid can have alteration gene expression in ploidy level [18]. Sequences of SNP markers in autotetraploid via hidden Markov models showed the quantity consequence for the distinction of quantitative characters, the interplay of the forms of gene and among loci [126]. When inserting TE, gene functions may alter and deactivate duplicated genes [127] and autopolyploid the Buckler Mustard occurred evolutionary dynamics of retrotransposons [128]. Study polysomic polyploid rice indicated that enhanced methylation to class II TEs could lead to suppressing the expression of adjacent genes that have gained duple alleles. The result was not a necessary alteration in transcriptome changes for furthermost genes derived after its diploid. This suggested that whole genome duplication causes methylation distinction in TEs that alter gene expression range and a "genome shock" response feature to associate neo-autopolyploids adaptation [110].

Polysomic polyploid are typically generated by colchicine. In recent articles, molecular levels of the chemical on multiplied genomes were identified by comparing a full range of messenger RNA expressed from doubled tetraploid orchardgrass root (D. glomerata subsp. smithii Link) when treated. It had 3381 DEGs (differently expression genes) under lack of water, and enhanced expression of 1258 DEGs in specimen DacR5tr under impacted by this chemical and in conjunction with an aquatic and anti-spindle substance. A gene ontology (GO) comparison showed DEGs pivotally controlled by colchicine enhanced some pathways such as cation binding, the catalytic process, and carrier action. A comparison to the KEGG (Kyoto Encyclopedia of Gene and Genome) showed processes of biosynthetic phenylpropanoid, metabolic phenylalanine, phytohormone cues transduction, and metabolic starch and saccharose. Colchicine decreased the microtubules and repressed transcription of cytokinesis that reduced the cell action and postpones the cell into the respiration pathway without oxygen to make a program of cell death at the end stage and reduced waterlog- 
ging. Additionally, colchicine inhibited transcripts associated with tubular cell structure, mitotic spindle, kinetochore-dependent chromosomes, vesicle, a constituent of cell wall and pathways of cytoplasm movement, chromatid separation, membrane, and cell wall growth [129].

Transcriptomes gained several plants (the 69 datasets of the total the messenger RNA molecules expressed) showing the impacts of genome merging and genome sizes. Gene relating to sequence-specific DNA-binding factors as well as cues transduction components has higher retention than normal levels. Increasing transcriptomes generated both inner and outer biological activities. For examples, external pathways emerged between cell wall metabolisms, transporters, and byproduct transformation. Internal processes consisted of the basic structural unit of proteins and their metabolisms. Whole genome duplications contributed to the role of diversities or novelties in increasing the plant acclimation to changing environments, due to higher rates of retention of a unit of heredity duplication for adjustive functions involving both environmental stress tolerance and biotic resistance [130] [131]. Genomic uniformity in the polysomic polyploid making its transcriptome was at a moderate level. Autotetraploidy derived from an intraspecific source of the genome doubling, so its changes of transcriptomes were less apparent comparing to allopolyploid. The levels of expression of almost alleles and dosage alternations in autopolyploid were a positive correlation. Several additive dosage genes controlled the developmental cell division, the process that uses light to synthesize sugar, and the pathways that change chemicals. While nonadditive dosage genes were associated with abiotic stress tolerance and biotic stress resistance [132].

\section{Conclusion and Perspectives}

In this review, recent studies on natural typed and resynthesized polysomic polyploid plants have shed light on the molecular mechanisms of gene expression as well as gene regulation in polyploidisation of the same species. Polysomic polyploid occurred possibly alternative transcriptomes tend to up-regulated genes linked to processes using light to enhance bioproducts, energy transformation, transcription factors, and cues transduction. Autotetraploid transcriptomes unraveled how to cell division and expansion, through controlling polar cell, conservating cell membranes' integrity, biosynthesizing components of the cell wall, regulating metabolites to carbohydrate and lipid, synthesizing of expansin, pectin, lignin, and byproducts. The stable genetic materials are due to DNA repair pathways, DNA methyltransferase, reorganizing the chromatin structure. Autopolyploid altered proteins are linked to coping with stress, transcription of aquaporin alleles, synthetic proline, genes having functions in phytohormones such as cytokinin, gibberellins, ethylene and auxin, antioxidant enzymes, and miRNAs playing a role in stress tolerance. The whole genome duplication leads to regulation through silencing genes or adjusting the expression levels through DNA elimination, methylation, gene suppression, subfunctionalization, neo-functionalization, and transposon functions (Figure 1). Polysomic polyploids have moderately 

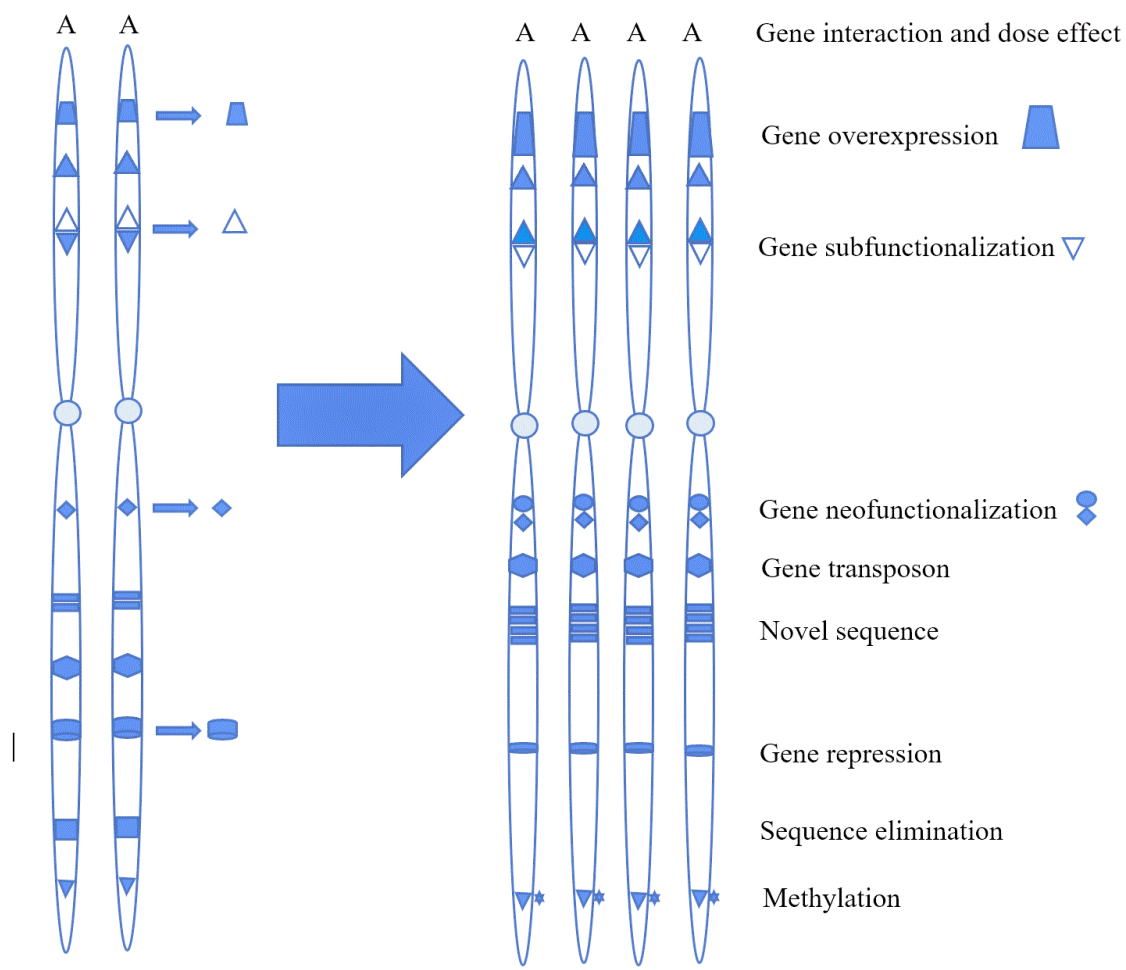

Figure 1. Diagram of genome duplication leading to change on structure and gene consequences in polysomic polyploids.

transcriptomes due to a genomic state of being uniform. This phenomenon originated from the same species leads to less obviously gene expression in comparison with allopolyploid.

Polysomic polyploid, the alternative chromosome contents, may adjust gene-regulating networks, genetic material reconstructions, and chromosome separation as well as higher energy using lead to reproductive effects and plant viability-they enhance a flexible genome occurring in the autotetraploid supported plant adaptation. Epigenetic can lead to hereditary alterations in autotetraploid with genetic adjustments, such as chromosome reorganizations, multiplication of repetitious sequences, and loss of DNA sequences. Several challenges occurred after autotetraploid, such as cell size effects, and nuclear volume related to DNA content, reprogramming of transcriptomes and the separation of more than two chromosome copies during mitosis and especially during gametogenesis. The results of the autotetraploid process occurred not only on the genetic, genome, proteome, and epigenetic levels but also on chromosomal stability, especially during meiosis. Several autotetraploid plants increase abiotic stress resistance and biotic resistance through the impacts of miRNAs on transcriptomes, which implies autopolyploid has an essential role in crop improvement. DNA methylations correlated with alternations in the gene expression of plants at different polyploid levels. These changes include methylation of cytosine that leads to both hypo- and hypermethylation in CG and CHG sites. DNA methylated in transcription factors might change in the expression of other genes. The 


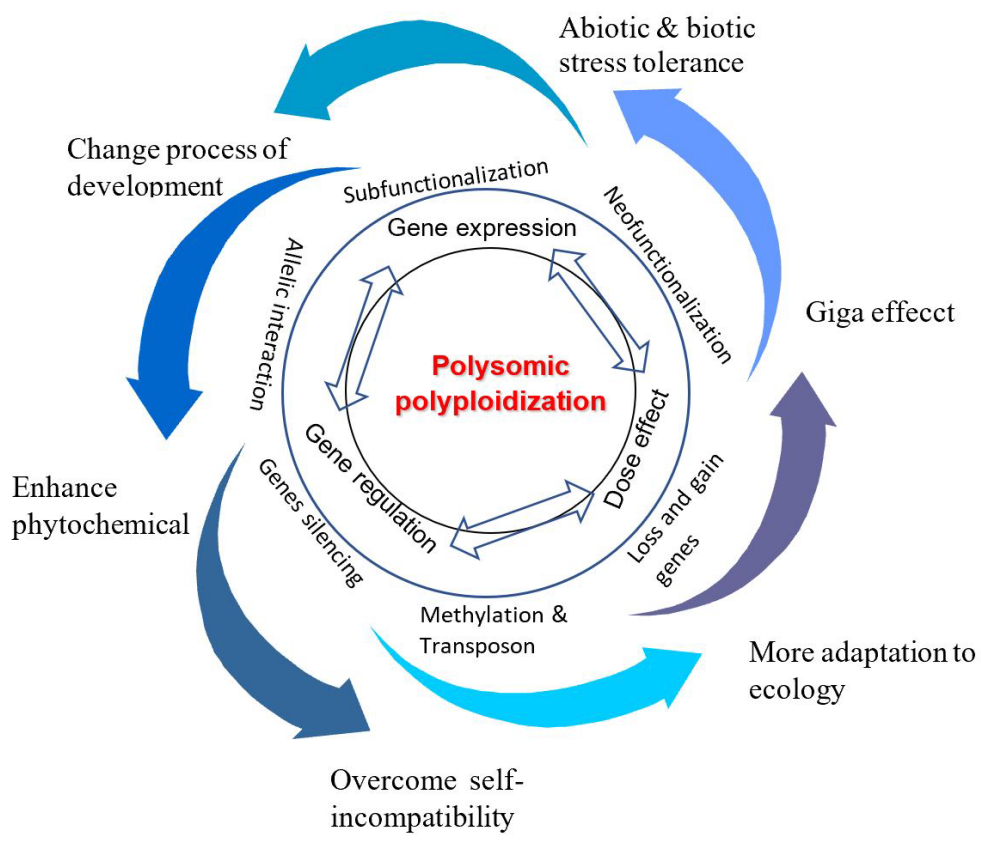

Figure 2. Diagram on gene expression and regulation leading to evolutionary fixed traits in polysomic polyploidy.

consequence of epigenetics may derive from the autopolyploid and the epigenetic environment of those species. The additive dosages suppressed TEs, but the crucial non-additive dosages are enhanced TE. Epigenetic changes are capacity-reversible and provide a flexible mechanism for autopolyploid cells to respond to adverse genomic alternations, particularly in the early stages of polyploid formation, leading to divergent genetic fluctuations. Additionally, many investigations have shown that epigenetic modifications help the gametogenesis in autotetraploid, motivating stability over generations. The study of autotetraploid transcriptomes revealed flexible and rapid mechanisms that were a response to both external and internal stimuli as like phytohormones. The challenges of a general analysis of the role of genomics and systematical biology were the association of data of metabolome, proteomes, and genomes to elucidate biological pathways including autopolyploidization. Furthermore, these dissections will also elucidate how polysomic polyploid contributes to speciation and biodiversification in the plant Kingdom.

The recent research papers on polysomic polyploid were discrete studies. These studies were independent and concerned specific fields such as how to make autopolyploid plants, how to evaluate phenotype, phytochemicals variation on diploid and polyploid with intraspecific resources or stress tolerance on different ploidy levels, etc. The studies did not display a correlative molecular mechanism between genotypes and traits of plants with polysomic polyploid. Therefore, generalized studies in plants are needed to understand polysomic polyploid by dissection all of epigenetic, metabolomic, transcriptomic and proteomic profiling to identify processes and mechanisms potentially responsible for phenotype varia- 
tion and environmental adaption associated with autopolyploidisation. The resurgence of interest in polyploid for the last decades has changed a previous hypothesis that polysomic polyploids are evolutionary dead-ends. In genetic studies, naturally occurring or resynthesized polysomic polyploids have been used to study dosage effects leading to interactions of gene expression and gene regulation that derived from allelic interaction, epigenetic, gene silencing, loss and gain genes, neofunctionalization and sub-functionalization in whole genome duplication crops. The molecular mechanism of polysomic polyploid rapidly changed in phenotype, biosynthetic pathway, enhanced the ability of tolerance to abiotic and biotic resistance, changed processes development, overcame self-incompatibility and more adaptation to ecology. More autopolyploid crops have developed and planted in the climate-change condition offer pathways in the future because they contained sources of agricultural traits that expect and desire (Figure 2).

\section{Acknowledgements}

The author is grateful to Prof. Dr. K. Watanabe, Univ. of Tsukuba, Japan and Prof. Dr. Syed Abudullah Gilani, University of Nizwa, Oman for critical reading and editing of the manuscript. This paper was supported in part by PTraD, the Center of Excellence on plant biotechnology under the Ministry of Education, Culture Sport, Science and Technology (MEXT) of the Government of Japan, at Tsukuba Plant Innovation Research Center, University of Tsukuba, Japan. Pham Van Hieu thanks the financial support from Ho Chi Minh City Government through HCMC Biotechnology center for his academic study and research in Japan.

\section{Conflicts of Interest}

The author declares no conflicts of interest regarding the publication of this paper.

\section{References}

[1] Lutz, A.M. (1907) A Prelimiary Note on the Chromosomes of Cenothera lamarckiana and One of Its Mutants, O. Gigas. Science, 26, 151-152. https://doi.org/10.1126/science.26.657.151

[2] Winge, O. (1917) The Chromosome. Their Numbers and General Importance. Comptes-rendus des travaux du Laboratoire Carlsberg, 13, 131-175.

[3] Kihara, H. and Ono, T. (1926) Chromosomenzahlen und Systematische Gruppierung der Rumex-Arten. Zeitschrift für Zellforschung und Mikroskopische Anatomie, 4, 475-481. https://doi.org/10.1007/BF00391215

[4] Buxton, B.H. and Darlington, C.D. (1931) Behaviour of a New Species, Digitalis Mertonensis. Nature, 127, 94. https://doi.org/10.1038/127094b0

[5] Karpechenko, G.D. (1927) The Production of Polyploid Gametes in Hybrids. Hereditas, 9, 349-368. https://doi.org/10.1111/j.1601-5223.1927.tb03536.x

[6] Müntzing, A. (1932) Cyto-Genetic Investigation on Synthetic Galeopsis tetrahit. Hereditas, 16, 105-154. https://doi.org/10.1111/j.1601-5223.1932.tb02564.x 
[7] Osborn, T.C., Pires, J.C., Birchler, J.A., Auger, D.L., Chen, Z.J., Lee, H.S., Comai, L., Madlung, A., Doerge, R.W., Colot, V. and Martienssen, R.A. (2003) Understanding Mechanisms of Novel Gene Expression in Polyploids. Trends in Genetics, 19, 141-147. https://doi.org/10.1016/S0168-9525(03)00015-5

[8] Key, J.M. (1970) Significance of Mating Systems for Chromosomes and Gametes in Polyploids. Hereditas, 66, 165-176. https://doi.org/10.1111/j.1601-5223.1970.tb02342.x

[9] Stebbins, G.L. (1947) Types of Polyploids: Their Classification and Significance. Advances in Genetics, 1, 403-429.

[10] Butruille, D.V. and Boiteux, L.S. (2000) Selection-Mutation Balance in Polysomic Tetraploids: Impact of Double Reduction and Gametophytic Selection on the Frequency and Subchromosomal Localization of Deleterious Mutations. Proceedings of the National Academy of Sciences of the United States of America, 97, 6608-6613. https://doi.org/10.1073/pnas.100101097

[11] Lloyd, A. and Bomblies, K. (2016) Meiosis in Autopolyploid and Allopolyploid Arabidopsis. Current Opinion in Plant Biology, 30, 116-122. https://doi.org/10.1016/j.pbi.2016.02.004

[12] Lu, Y., Yang, X., Tong, C., Li, X., Feng, S., Wang, Z., Pang, X., Wang, Y., Wang, N., Tobias, C.M. and Wu, R. (2013) A Multivalent Three-Point Linkage Analysis Model of Autotetraploids. Briefings in Bioinformatics, 14, 460-468. https://doi.org/10.1093/bib/bbs051

[13] Barker, M.S., Husband, B.C. and Pires, J.C. (2016) Spreading Winge and Flying High: The Evolutionary Importance of Polyploidy after a Century of Study. American Journal of Botany, 103, 1139-1145. https://doi.org/10.3732/ajb.1600272

[14] Soltis, D.E., Segovia-Salcedo, M.C., Jordon-Thaden, I., Majure, L., Miles, N.M., Mavrodiev, E.V., Mei, W., Cortez, M.B., Soltis,S. and Gitzendanner, M.A. (2014) Are Polyploids Really Evolutionary Dead-Ends (again)? A Critical Reappraisal of Mayrose et al. (2011). The New Phytologist, 202, 1105-1117. https://doi.org/10.1111/nph.12756

[15] Mayrose, I., Zhan, S.H., Rothfels, C.J., Arrigo, N., Barker, M.S., Rieseberg, L.H. and Otto, S.P. (2015) Methods for Studying Polyploid Diversification and the Dead End Hypothesis: A Reply to Soltis et al. (2014). New Phytologist, 206, 27-35. https://doi.org/10.1111/nph.13192

[16] Spoelhof, J.P., Soltis, S. and Soltis, D.E. (2017) Pure Polyploidy: Closing the Gaps in Autopolyploid Research. Journal of Systematics and Evolution, 55, 340-352. https://doi.org/10.1111/jse.12253

[17] Barker, M.S., Arrigo, N., Baniaga, A.E., Li, Z. and Levin, D.A. (2016) On the Relative Abundance of Autopolyploids and Allopolyploids. New phytologist, 210, 391-398. https://doi.org/10.1111/nph.13698

[18] Watanabe, K. (2015) Potato Genetics, Genomics and Applications. Breeding Science, 65, 53-68. https://doi.org/10.1270/jsbbs.65.53

[19] Luo, Z.W., Zhang, Z., Zhang, R.M., Pandey, M., Gailing, O., Hattemer, H.H. and Finkeldey, R. (2006) Modeling Population Genetic Data in Autotetraploid Species. Genetics, 172, 639-646. https://doi.org/10.1534/genetics.105.044974

[20] Soltis, S. and Soltis, D.E. (2000) The Role of Genetic and Genomic Attributes in the Success of Polyploids. Proceedings of the National Academy of Sciences of the United States of America, 97, 7051-7057. https://doi.org/10.1073/pnas.97.13.7051

[21] Salman-Minkov, A., Sabath, N. and Mayrose, I. (2016) Whole-Genome Duplication 
as a Key Factor in Crop Domestication. Nature Plants, 2, Article No. 16115. https://doi.org/10.1038/nplants.2016.115

[22] Mammadov, J., Buyyarapu, R., Guttikonda, S.K., Parliament, K., Abdurakhmonov, I.Y. and Kumpatla, S.P. (2018) Wild Relatives of Maize, Rice, Cotton and Soybean: Treasure Troves for Tolerance to Biotic and Abiotic Stresses. Frontiers in Plant Science, 9, 886. https://doi.org/10.3389/fpls.2018.00886

[23] Machida-Hirano, R. (2015) Diversity of Potato Genetic Resources. Breeding Science, 65, 26-40. https://doi.org/10.1270/jsbbs.65.26

[24] Bethke, P.C., Halterman, D. and Jansky, S. (2017) Are We Getting Better at Using Wild Potato Species in Light of New Tools? Crop Science, 57, 1241-1258. https://doi.org/10.2135/cropsci2016.10.0889

[25] Flint-Garcia, S.A. (2013) Genetics and Consequences of Crop Domestication. Journal of Agricultural and Food Chemistry, 61, 8267-8276. https://doi.org/10.1021/jf305511d

[26] Hancock, J.F. (2005) Contributions of Domesticated Plant Studies to our Understanding of Plant Evolution. Annals of Botany, 96, 953-963. https://doi.org/10.1093/aob/mci259

[27] Vaughan, D.A., Balázs, E. and Heslop-Harrison, J.S. (2007) From Crop Domestication to Super-Domestication. Annals of Botany, 100, 893-901. https://doi.org/10.1093/aob/mcm224

[28] Dar, J., Beigh, Z. and Wani, A.A. (2017) Polyploidy: Evolution and Crop Improvement. In: Bhat, T. and Wani, A., Eds., Chromosome Structure and Aberrations, Springer, New Delhi, 201-218. https://doi.org/10.1007/978-81-322-3673-3_10

[29] Soltis, D.E., Albert, V.A., Leebens-Mack, J., Bell, C.D., Paterson, A.H., Zheng, C., Sankoff, D., Depamphilis, C.W., Wall, K. and Soltis, S. (2009) Polyploidy and Angiosperm Diversification. American Journal of Botany, 96, 336-348. https://doi.org/10.3732/ajb.0800079

[30] Jiao, Y., Wickett, N.J., Ayyampalayam, S., Chanderbali, A.S., Landherr, L., Ralph, E., Tomsho, L.P., Hu, Y., Liang, H., Soltis, S., Soltis, D.E., Clifton, S.W., Schlarbaum, S.E., Schuster, S.C., Ma, H., Leebens-Mack, J. and dePamphilis, C.W. (2011) Ancestral Polyploidy in Seed Plants and Angiosperms. Nature, 473, 97-100. https://doi.org/10.1038/nature09916

[31] Parisod, C., Holderegger, R. and Brochmann, C. (2010) Evolutionary Consequences of Autopolyploidy. New Phytologist, 186, 5-17. https://doi.org/10.1111/j.1469-8137.2009.03142.x

[32] Van de Peer, Y., Mizrachi, E. and Marchal, K. (2017) The Evolutionary Significance of Polyploidy. Nature Reviews Genetics, 18, 411-424. https://doi.org/10.1038/nrg.2017.26

[33] Drunen, W. and Husband, B.C. (2018) Immediate vs. Evolutionary Consequences of Polyploidy on Clonal Reproduction in an Autopolyploid Plant. Annals of Botany, 122, 195-205. https://doi.org/10.1093/aob/mcy071

[34] Jiao, Y. (2018) Double the Genome, Double the Fun: Genome Duplications in Angiosperms. New Phytologist, 11, 357-358. https://doi.org/10.1016/j.molp.2018.02.009

[35] Miller, M., Zhang, C. and Chen, Z.J. (2012) Ploidy and Hybridity Effects on Growth Vigor and Gene Expression in Arabidopsis thaliana Hybrids and Their Parents. G3: Genes, Genomes, Genetics, 2, 505-513. https://doi.org/10.1534/g3.112.002162

[36] Novikova, Y., Hohmann, N. and Van de Peer, Y. (2018) Polyploid Arabidopsis Spe- 
cies Originated around Recent Glaciation Maxima. Current Opinion in Plant Biology, 42, 8-15. https://doi.org/10.1016/j.pbi.2018.01.005

[37] Soltis, S. and Soltis, D.E. (2016) Ancient WGD Events as Drivers of Key Innovations in Angiosperms. Current Opinion in Plant Biology, 30, 159-165.

https://doi.org/10.1016/j.pbi.2016.03.015

[38] Semon, M. and Wolfe, K.H. (2007) Consequences of Genome Duplication. Current Opinion in Genetics \& Development, 17, 505-512. https://doi.org/10.1016/j.gde.2007.09.007

[39] Albuzio, A., Spettoli, P. and Cacco, G. (1978) Changes in Gene Expression from Diploid to Autotetraploid Status of Lycopersicum esculentum. Physiologia Plantarum, 44, 77-80. https://doi.org/10.1111/j.1399-3054.1978.tb01617.x

[40] Chung, H.H., Shi, S.K., Huang, B. and Chen, J.T. (2017) Enhanced Agronomic Traits and Medicinal Constituents of Autotetraploids in Anoectochilus formosanus Hayata, a Top-Grade Medicinal Orchid. Molecules, 22, 1907. https://doi.org/10.3390/molecules22111907

[41] Dou, J., Yuan, P.-L., Zhao, S., He, N., Zhu, H., Gao, L., Ji, W., Lu, X. and Liu, W. (2017) Effect of Ploidy Level on Expression of Lycopene Biosynthesis Genes and Accumulation of Phytohormones during Watermelon (Citrullus lanatus) Fruit Development and Ripening. Journal of Integrative Agriculture, 16, 1956-1967. https://doi.org/10.1016/S2095-3119(16)61618-0

[42] Javadian, N., Karimzadeh, G., Sharifi, M., Moieni, A. and Behmanesh, M. (2017) In Vitro Polyploidy Induction: Changes in Morphology, Podophyllotoxin Biosynthesis and Expression of the Related Genes in Linum album (Linaceae). Planta, 245, 1165-1178. https://doi.org/10.1007/s00425-017-2671-2

[43] Mishra, B.K., Pathak, S., Sharma, A., Trivedi, K. and Shukla, S. (2010) Modulated Gene Expression in Newly Synthesized Auto-Tetraploid of Papaver somniferum L. South African Journal of Botany, 76, 447-452. https://doi.org/10.1016/j.sajb.2010.02.090

[44] Saminathan, T., Nimmakayala,, Manohar, S., Malkaram, S., Almeida, A., Cantrell, R., Tomason, Y., Abburi, L., Rahman, M.A., Vajja, V.G., Khachane, A., Kumar, B., Rajasimha, H.K., Levi, A., Wehner, T. and Reddy, U.K. (2015) Differential Gene Expression and Alternative Splicing between Diploid and Tetraploid Watermelon. Journal of Experimental Botany, 66, 1369-1385. https://doi.org/10.1093/jxb/eru486

[45] De Smet, R., Sabaghian, E., Li, Z., Saeys, Y. and Van de Peer, Y. (2017) Coordinated Functional Divergence of Genes after Genome Duplication in Arabidopsis thaliana. The Plant Cell, 29, 2786-2800. https://doi.org/10.1105/tpc.17.00531

[46] Zhou, Y., Kang, L., Liao, S., Pan, Q., Ge, X. and Li, Z. (2015) Transcriptomic Analysis Reveals Differential Gene Expressions for Cell Growth and Functional Secondary Metabolites in Induced Autotetraploid of Chinese Woad (Isatis indigotica Fort.). PLoS ONE, 10, e0116392. https://doi.org/10.1371/journal.pone.0116392

[47] Martelotto, L.G., Ortiz, J.P.A., Stein, J., Espinoza, F., Quarin, C.L. and Pessino, S.C. (2005) A Comprehensive Analysis of Gene Expression Alterations in a Newly Synthesized Paspalum notatum Autotetraploid. Plant Science, 169, 211-220. https://doi.org/10.1016/j.plantsci.2005.03.015

[48] Lu, B., Ding, R., Zhang, L., Yu, X., Huang, B. and Chen, W. (2006) Molecular Cloning and Characterization of a Novel Calcium-Dependent Protein Kinase Gene IiCPK2 Responsive to Polyploidy from Tetraploid Isatis Indigotica. Journal of Biochemistry and Molecular Biology, 39, 607-617.

https://doi.org/10.5483/BMBRep.2006.39.5.607 
[49] Lu, B., Pan, X., Zhang, L., Huang, B., Sun, L., Li, B., Yi, B., Zheng, S., Yu, X., Ding, R. and Chen, W. (2006) A Genome-Wide Comparison of Genes Responsive to Autopolyploidy in Isatis indigotica Using Arabidopsis thaliana Affymetrix Genechips. Plant Molecular Biology Reporter, 24, 197-204. https://doi.org/10.1007/BF02914058

[50] Liu, B. and Sun, G. (2017) MicroRNAs Contribute to Enhanced Salt Adaptation of the Autopolyploid Hordeum bulbosum Compared with Its Diploid Ancestor. The Plant Journal, 91, 57-69. https://doi.org/10.1111/tpj.13546

[51] Mu, H., Liu, Z., Lin, L., Li, H., Jiang, J. and Liu, G. (2012) Transcriptomic Analysis of Phenotypic Changes in Birch (Betula platyphylla) Autotetraploids. International Journal of Molecular Sciences, 13, 13012-13029. https://doi.org/10.3390/ijms131013012

[52] Zhang, X., Deng, M. and Fan, G. (2014) Differential Transcriptome Analysis between Paulownia fortunei and Its Synthesized Autopolyploid. International Journal of Molecular Sciences, 15, 5079-5093. https://doi.org/10.3390/ijms15035079

[53] Zhao, Z., Li, Y., Liu, H., Zhai, X., Deng, M., Dong, Y. and Fan, G. (2017) Genome-Wide Expression Analysis of Salt-Stressed Diploid and Autotetraploid Paulownia tomentosa. PLoS ONE, 12, e0185455. https://doi.org/10.1371/journal.pone.0185455

[54] Cao, X., Fan, G., Cao, L., Deng, M., Zhao, Z., Niu, S., Wang, Z. and Wang, Y. (2017) Drought Stress-Induced Changes of MicroRNAs in Diploid and Autotetraploid Paulownia tomentosa. Genes \& Genomics, 39, 77-86. https://doi.org/10.1007/s13258-016-0473-8

[55] Niu, S., Wang, Y., Zhao, Z., Deng, M., Cao, L., Yang, L. and Fan, G. (2016) Transcriptome and Degradome of MicroRNAs and Their Targets in Response to Drought Stress in the Plants of a Diploid and Its Autotetraploid Paulownia australis. PLoS ONE, 11, e0158750. https://doi.org/10.1371/journal.pone.0158750

[56] Zhao, Z., Niu, S., Fan, G., Deng, M. and Wang, Y. (2018) Genome-Wide Analysis of Gene and MicroRNA Expression in Diploid and Autotetraploid Paulownia fortunei (Seem) Hemsl. under Drought Stress by Transcriptome, MicroRNA and Degradome Sequencing. Forests, 9, 88. https://doi.org/10.3390/f9020088

[57] Dai, F., Wang, Z., Luo, G. and Tang, C. (2015) Phenotypic and Transcriptomic Analyses of Autotetraploid and Diploid Mulberry (Morus alba L.). International Journal of Molecular Sciences, 16, 22938-22956. https://doi.org/10.3390/ijms160922938

[58] Xue, H., Zhang, F., Zhang, Z.-H., Fu, J.-F., Wang, F., Zhang, B. and Ma, Y. (2015) Differences in Salt Tolerance between Diploid and Autotetraploid Apple Seedlings Exposed to Salt Stress. Scientia Horticulturae, 190, 24-30. https://doi.org/10.1016/j.scienta.2015.04.009

[59] Pegoraro, L., Cafasso, D., Rinaldi, R., Cozzolino, S. and Scopece, G. (2016) Habitat Preference and Flowering-Time Variation Contribute to Reproductive Isolation Between Diploid and Autotetraploid Anacamptis pyramidalis. Journal of Evolutionary Biology, 29, 2070-2082. https://doi.org/10.1111/jeb.12930

[60] Münzbergová, Z. and Skuhrovec, J. (2017) Contrasting Effects of Ploidy Level on Seed Production in a Diploid-Tetraploid System. AoB Plants, 9, plw077. https://doi.org/10.1093/aobpla/plw077

[61] Hollister, J.D., Arnold, B.J., Svedin, E., Xue, K.S., Dilkes, B.P. and Bomblies, K. (2012) Genetic Adaptation Associated with Genome-Doubling in Autotetraploid Arabidopsis arenosa. PLoS Genetics, 8, e1003093. 
https://doi.org/10.1371/journal.pgen.1003093

[62] Rastogi, S. and Liberles, D.A. (2005) Subfunctionalization of Duplicated Genes as a Transition State to Neofunctionalization. BMC Evolutionary Biology, 5, 28. https://doi.org/10.1186/1471-2148-5-28

[63] Conant, G.C. and Wolfe, K.H. (2008) Turning a Hobby into a Job: How Duplicated Genes Find New Functions. Nature Reviews Genetics, 9, 938-950. https://doi.org/10.1038/nrg2482

[64] Gu, A.X., Zhao, J.J., Li, L.M., Wang, Y.H., Zhao, Y.J., Hua, F., Xu, Y.C. and Shen, S.X. (2016) Analyses of Phenotype and ARGOS and ASY1 Expression in a Ploidy Chinese Cabbage Series Derived from One Haploid. Breeding Science, 66, 161-168.

[65] Halterman, D., Guenthner, J., Collinge, S., Butler, N. and Douches, D. (2016) Biotech Potatoes in the 21st Century: 20 Years Since the First Biotech Potato. American Journal of Potato Research, 93, 1-20. https://doi.org/10.1007/s12230-015-9485-1

[66] Wang, B., Sang, Y., Song, J., Gao, X.Q. and Zhang, X. (2009) Expression of a Rice OsARGOS Gene in Arabidopsis Promotes Cell Division and Expansion and Increases Organ Size. Journal of Genetics and Genomics 36, 31-40. https://doi.org/10.1016/S1673-8527(09)60004-7

[67] Bird, D., Beisson, F., Brigham, A., Shin, J., Greer, S., Jetter, R., Kunst, L., Wu, X., Yephremov, A. and Samuels, L. (2007) Characterization of Arabidopsis ABCG11/WBC11, an ATP Binding Cassette (ABC) Transporter that Is Required for Cuticular Lipid Secretion. The Plant Journal, 52, 485-498. https://doi.org/10.1111/j.1365-313X.2007.03252.x

[68] Narukawa, H., Yokoyama, R., Komaki, S., Sugimoto, K. and Nishitani, K. (2015) Stimulation of Cell Elongation by Tetraploidy in Hypocotyls of Dark-Grown Arabidopsis Seedlings. PLoS ONE, 10, e0134547. https://doi.org/10.1371/journal.pone.0134547

[69] Narukawa, H., Yokoyama, R. and Nishitani, K. (2016) Possible Pathways Linking Ploidy Level to Cell Elongation and Cuticular Function in Hypocotyls of Dark-Grown Arabidopsis Seedlings. Plant Signaling \& Behavior, 11, e1118597. https://doi.org/10.1080/15592324.2015.1118597

[70] Corneillie, S., De Storme, N., Van Acker, R., Fangel, J.U., De Bruyne, M., De Rycke, R., Geelen, D., Willats, W.G.T., Vanholme, B. and Boerjan, W. (2019) Polyploidy Affects Plant Growth and Alters Cell Wall Composition. Plant Physiology, 179, 74-87. https://doi.org/10.1104/pp.18.00967

[71] Alam, H., Razaq, M. and Salahuddin (2015) Induced Polyploidy as a Tool for Increasing Tea (Camellia sinensis L.) Production. Journal of Northeast Agricultural University, 22, 43-47. https://doi.org/10.1016/S1006-8104(16)30005-8

[72] Ma, Y., Xue, H., Zhang, L., Zhang, F., Ou, C., Wang, F. and Zhang, Z. (2016) Involvement of Auxin and Brassinosteroid in Dwarfism of Autotetraploid Apple (Malus $\times$ domestica). Scientific Reports, 6, 26719. https://doi.org/10.1038/srep26719

[73] Allario, T., Brumos, J., Colmenero-Flores, J.M., Tadeo, F., Froelicher, Y., Talon, M., Navarro, L., Ollitrault, P. and Morillon, R. (2011) Large Changes in Anatomy and Physiology between Diploid Rangpur Lime (Citrus limonia) and Its Autotetraploid Are Not Associated with Large Changes in Leaf Gene Expression. Journal of Experimental Botany, 62, 2507-2519. https://doi.org/10.1093/jxb/erq467

[74] Wang, Z., Fan, G., Dong, Y., Zhai, X., Deng, M., Zhao, Z., Liu, W. and Cao, Y. (2017) Implications of Polyploidy Events on the Phenotype, Microstructure and Proteome of Paulownia australis. PLOS ONE, 12, e0172633.

https://doi.org/10.1371/journal.pone.0172633 
[75] Pelé, A., Rousseau-Gueutin, M. and Chèvre, A.-M. (2018) Speciation Success of Polyploid Plants Closely Relates to the Regulation of Meiotic Recombination. Frontiers in Plant Science, 9, 907. https://doi.org/10.3389/fpls.2018.00907

[76] Wu, J., Shahid, M.Q., Guo, H., Yin, W., Chen, Z., Wang, L., Liu, X. and Lu, Y. (2014) Comparative Cytological and Transcriptomic Analysis of Pollen Development in Autotetraploid and Diploid Rice. Plant Reproduction, 27, 181-196. https://doi.org/10.1007/s00497-014-0250-2

[77] Wright, K.M., Arnold, B., Xue, K., Šurinová, M., O’Connell, J. and Bomblies, K. (2015) Selection on Meiosis Genes in Diploid and Tetraploid Arabidopsis arenosa. Molecular Biology and Evolution, 32, 944-955. https://doi.org/10.1093/molbev/msu398

[78] Da Ines, O., Degroote, F., Goubely, C., Amiard, S., Gallego, M.E. and White, C.I. (2013) Meiotic Recombination in Arabidopsis Is Catalysed by DMC1, with RAD51 Playing a Supporting Role. PLoS Genetics, 9, e1003787. https://doi.org/10.1371/journal.pgen.1003787

[79] Braynen, J., Yang, Y., Wei, F., Cao, G., Shi, G., Tian, B., Zhang, X., Jia, H., Wei, X. and Wei, Z. (2017) Transcriptome Analysis of Floral Buds Deciphered an Irregular Course of Meiosis in Polyploid Brassica rapa. Front Plant Science, 8, 768. https://doi.org/10.3389/fpls.2017.00768

[80] Li, X., Shahid, M.Q., Xia, J., Lu, Z., Fang, N., Wang, L., Wu, J., Chen, Z. and Liu, X. (2017) Analysis of Small RNAs Revealed Differential Expressions during Pollen and Embryo Sac Development in Autotetraploid Rice. BMC Genomics, 18, 129. https://doi.org/10.1186/s12864-017-3526-8

[81] Liu, W., Zhao, S., Cheng, Z., Wan, X., Yan, Z. and King, S.R. (2010) Lycopene and Citrulline Contents in Watermelon (Citrullus lanatus) Fruit with Different Ploidy and Changes during Fruit Development. Acta Horticulturae, 871, 543-550. https://doi.org/10.17660/ActaHortic.2010.871.75

[82] Zhao, W., Lv, P. and Gu, H. (2013) Studies on Carotenoids in Watermelon Flesh. Agricultural Sciences, 4, 13-20. https://doi.org/10.4236/as.2013.47A003

[83] Vergara, F., Kikuchi, J. and Breuer, C. (2016) Artificial Autopolyploidization Modifies the Tricarboxylic Acid Cycle and GABA Shunt in Arabidopsis thaliana Col-0. Scientific Reports, 6, 26515. https://doi.org/10.1038/srep26515

[84] Preet, R. and Gupta, R.C. (2017) Fatty Acid Profiling in Diploid (n = 12) and Tetraploid Cytotypes $(\mathrm{n}=24)$ of Physalis angulata LINN from Rajasthan by Gas Chromatography International Journal of Pharmaceutical Sciences and Research, $\mathbf{8}$, 3458-3462.

[85] Tu, Y., Jiang, A., Gan, L., Hossain, M., Zhang, J., Peng, B., Xiong, Y., Song, Z., Cai, D., Xu, W., Zhang, J. and He, Y. (2014) Genome Duplication Improves Rice Root Resistance to Salt Stress. Rice, 7, 15. https://doi.org/10.1186/s12284-014-0015-4

[86] Visger, C., Wong, G.K.S., Zhang, Y., Soltis, S. and Soltis, D.E. (2017) Divergent Gene Expression Levels between Diploid and Autotetraploid Tolmiea (Saxifragaceae) Relative to the Total Transcriptome, the Cell and Biomass. BioRxiv, 1-35. https://doi.org/10.1101/169367

[87] Fan, G., Wang, L., Deng, M., Niu, S., Zhao, Z., Xu, E., Cao, X. and Zhang, X. (2015) Transcriptome Analysis of the Variations between Autotetraploid Paulownia tomentosa and Its Diploid Using High-Throughput Sequencing. Molecular Genetics and Genomics, 290, 1627-1638. https://doi.org/10.1007/s00438-015-1023-9

[88] Fasano, C., Diretto, G., Aversano, R., D’Agostino, N., Di Matteo, A., Frusciante, L., Giuliano, G. and Carputo, D. (2016) Transcriptome and Metabolome of Synthetic 
Solanum Autotetraploids Reveal Key Genomic Stress Events Following Polyploidization. New Phytologist, 210, 1382-1394. https://doi.org/10.1111/nph.13878

[89] Tsukaya, H., Sawada, Y., Oikawa, A., Shiratake, K., Isuzugawa, K., Saito, K. and Hirai, M.Y. (2015) Intraspecific Comparative Analyses of Metabolites between Diploid and Tetraploid Arabidopsis thaliana and Pyrus communis. New Negatives in Plant Science, 1-2, 53-61.

[90] Vergara, F., Rymen, B., Kuwahara, A., Sawada, Y., Sato, M. and Hirai, M.Y. (2017) Autopolyploidization, Geographic Origin and Metabolome Evolution in Arabidopsis thaliana. American Journal of Botany, 104, 905-914. https://doi.org/10.3732/ajb.1600419

[91] Yan, K., Wu, C., Zhang, L. and Chen, X. (2015) Contrasting Photosynthesis and Photoinhibition in Tetraploid and Its Autodiploid Honeysuckle (Lonicera japonica Thunb.) under Salt Stress. Frontiers in Plant Science, 6, 227. https://doi.org/10.3389/fpls.2015.00227

[92] Meng, H., Jiang, S., Hua, S., Lin, X., Li, Y., Guo, W. and Jiang, L. (2011) Comparison between a Tetraploid Turnip and Its Diploid Progenitor (Brassica rapa L.): The Adaptation to Salinity Stress. Agricultural Sciences in China, 10, 363-375. https://doi.org/10.1016/S1671-2927(11)60015-1

[93] Yu, L., Liu, X., Boge, W. and Liu, X. (2016) Genome-Wide Association Study Identifies Loci for Salt Tolerance during Germination in Autotetraploid Alfalfa (Medicago sativa L.) Using Genotyping-by-Sequencing. Frontiers in Plant Science, 7, 956. https://doi.org/10.3389/fpls.2016.00956

[94] Chao, D.Y., Dilkes, B., Luo, H., Douglas, A., Yakubova, E., Lahner, B. and Salt, D.E. (2013) Polyploids Exhibit Higher Potassium Uptake and Salinity Tolerance in Arabidopsis. Science, 341, 658-659. https://doi.org/10.1126/science.1240561

[95] Fan, G., Li, X., Deng, M., Zhao, Z. and Yang, L. (2016) Comparative Analysis and Identification of miRNAs and Their Target Genes Responsive to Salt Stress in Diploid and Tetraploid Paulownia fortunei Seedlings. PLoS ONE, 11, e0149617. https://doi.org/10.1371/journal.pone.0149617

[96] Li, M., Xu, G., Xia, X., Wang, M., Yin, X., Zhang, B., Zhang, X. and Cui, Y. (2017) Deciphering the Physiological and Molecular Mechanisms for Copper Tolerance in Autotetraploid Arabidopsis. Plant Cell Reports, 36, 1585-1597. https://doi.org/10.1007/s00299-017-2176-2

[97] Zhang, X.Y., Hu, C.G. and Yao, J.L. (2010) Tetraploidization of Diploid Dioscorea Results in Activation of the Antioxidant Defense System and Increased Heat Tolerance. Journal of Plant Physiology, 167, 88-94. https://doi.org/10.1016/j.jplph.2009.07.006

[98] Mu, H., Lin, L., Zhang, Q., Tang, X., Zhang, X. and Cheng, G. (2016) Growth, Proline Content and Proline-Associated Gene Expression of Autotetraploid Betula platyphylla Responding to $\mathrm{NaHCO}_{3}$ Stress. Dendrobiology, 75, 123-129.

[99] El-Morsy, S., Dorra, D.M.M., El-Hady, A., Hiaba, A.A.A. and Mohamed, Y.A. (2009) Comparative Studies on Diploid and Tetraploid Levels of Nicotiana alata. Academic Journal of Plant Sciences, 2, 182-188.

[100] Ruiz, M., Quiñones, A., Martínez-Alcántara, B., Aleza, P., Morillon, R., Navarro, L., Primo-Millo, E. and Martínez-Cuenca, M. (2016) Tetraploidy Enhances Boron-Excess Tolerance in Carrizo Citrange (Citrus sinensis L. Osb. $\times$ Poncirus trifoliata L. Raf.). Frontiers in Plant Science, 7, 701. https://doi.org/10.3389/fpls.2016.00701

[101] Yan, L., Fan, G., Deng, M., Zhao, Z., Dong, Y. and Li, Y. (2017) Comparative Proteomic Analysis of Autotetraploid and Diploid Paulownia tomentosa Reveals Pro- 
teins Associated with Superior Photosynthetic Characteristics and Stress Adaptability in Autotetraploid Paulownia. Physiology and Molecular Biology of Plants, 23, 605-617. https://doi.org/10.1007/s12298-017-0447-6

[102] Deng, M., Dong, Y., Zhao, Z., Li, Y. and Fan, G. (2017) Dissecting the Proteome Dynamics of the Salt Stress Induced Changes in the Leaf of Diploid and Autotetraploid Paulownia fortunei. PLoS ONE, 12, e0181937. https://doi.org/10.1371/journal.pone.0181937

[103] del Pozo, J.C. and Ramirez-Parra, E. (2014) Deciphering the Molecular Bases for Drought Tolerance in Arabidopsis Autotetraploids. Plant, Cell \& Environment, 37, 2722-2737. https://doi.org/10.1111/pce.12344

[104] Deng, B., Du, W., Liu, C., Sun, W., Tian, S. and Dong, H. (2012) Antioxidant Response to Drought, Cold and Nutrient Stress in Two Ploidy Levels of Tobacco Plants: Low Resource Requirement Confers Polytolerance in Polyploids? Plant Growth Regulation, 66, 37-47. https://doi.org/10.1007/s10725-011-9626-6

[105] Hias, N., Svara, A. and Keulemans, J.W. (2018) Effect of Polyploidisation on the Response of Apple (Malus $\times$ domestica Borkh.) to Venturia inaequalis Infection. European Journal of Plant Pathology, 151, 515-526. https://doi.org/10.1007/s10658-017-1395-2

[106] Gao, R., Wang, H., Dong, B., Yang, X., Chen, S., Jiang, J., Zhang, Z., Liu, C., Zhao, N. and Chen, F. (2016) Morphological, Genome and Gene Expression Changes in Newly Induced Autopolyploid Chrysanthemum lavandulifolium (Fisch. ex Trautv.) Makino. International Journal of Molecular Sciences, 17, 1690. https://doi.org/10.3390/ijms17101690

[107] De Smet, R., Adams, K.L., Vandepoele, K., Van Montagu, M.C.E., Maere, S. and Van de Peer, Y. (2013) Convergent Gene Loss Following Gene and Genome Duplications Creates Single-Copy Families in Flowering Plants. Proceedings of the National Academy of Sciences of the United States of America, 110, 2898-2903. https://doi.org/10.1073/pnas.1300127110

[108] Stupar, R.M., Bhaskar, B., Yandell, B.S., Rensink, W.A., Hart, A.L., Ouyang, S., Veilleux, R.E., Busse, J.S., Erhardt, R.J., Buell, C.R. and Jiang, J. (2007) Phenotypic and Transcriptomic Changes Associated With Potato Autopolyploidization. Genetics, 176, 2055-2067. https://doi.org/10.1534/genetics.107.074286

[109] Zhang, H., Zhao, H., Wu, S., Huang, F., Wu, K., Zeng, X., Chen, X., Xu, and Wu, X. (2016) Global Methylation Patterns and Their Relationship with Gene Expression and Small RNA in Rice Lines with Different Ploidy. Frontiers in Plant Science, 7, 1002. https://doi.org/10.3389/fpls.2016.01002

[110] Zhang, J., Liu, Y., Xia, E., Yao, Q., Liu, X. and Gao, L. (2015) Autotetraploid Rice Methylome Analysis Reveals Methylation Variation of Transposable Elements and Their Effects on Gene Expression. Proceedings of the National Academy of Sciences of the United States of America, 112, E7022-E7029.

https://doi.org/10.1073/pnas.1515170112

[111] Lavania, U.C., Srivastava, S., Lavania, S., Basu, S., Misra, N.K. and Mukai, Y. (2012) Autopolyploidy Differentially Influences Body Size in Plants, but Facilitates Enhanced Accumulation of Secondary Metabolites, Causing Increased Cytosine $\mathrm{Me}$ thylation. Plant Journal, 71, 539-549.

https://doi.org/10.1111/j.1365-313X.2012.05006.x

[112] Church, S.A. and Spaulding, E.J. (2009) Gene Expression in a Wild Autopolyploid Sunflower Series. Journal of Heredity, 100, 491-495.

https://doi.org/10.1093/jhered/esp008 
[113] Dong, B., Wang, H., Song, A., Liu, T., Chen, Y., Fang, W., Chen, S., Chen, F., Guan, Z. and Jiang, J. (2016) miRNAs Are Involved in Determining the Improved Vigor of Autotetrapoid Chrysanthemum nankingense. Frontiers in Plant Science, 7, 1412. https://doi.org/10.3389/fpls.2016.01412

[114] Xu, Y., Zhang, W., Chen, G. and Wang, J. (2017) DNA Methylation Alteration Is a Major Consequence of Genome Doubling in Autotetraploid Brassica rapa. Archives of Biological Sciences, 69, 689-697.

[115] He, P., Cheng, L., Li, H., Wang, H. and Li, L. (2017) A Comparative Analysis of DNA Methylation in Diploid and Tetraploid Apple (Malus $\times$ domestica Borkh.). Czech Journal of Genetics and Plant Breeding, 53, 63-68. https://doi.org/10.17221/55/2016-CJGPB

[116] Dar, T.H., Raina, S.N. and Goel, S. (2017) Cytogenetic and Molecular Evidences Revealing Genomic Changes after Autopolyploidization: A Case Study of Synthetic Autotetraploid Phlox drummondii Hook. Physiology and Molecular Biology of Plants, 23, 641-650. https://doi.org/10.1007/s12298-017-0445-8

[117] Liu, S., Yang, Y., Wei, F., Duan, J., Braynen, J., Tian, B., Cao, G., Shi, G. and Yuan, J. (2017) Autopolyploidy Leads to Rapid Genomic Changes in Arabidopsis thaliana. Theory in Biosciences, 136, 199-206. https://doi.org/10.1007/s12064-017-0252-3

[118] Arsovski, A.A. and Pradinuk, J. (2015) Evolution of Cis-Regulatory Elements and Regulatory Networks in Duplicated Genes of Arabidopsis. Plant Physiology, 169, 2982-2991. https://doi.org/10.1104/pp.15.00717

[119] Qiao, G., Liu, M., Song, K., Li, H., Yang, H., Yin, Y. and Zhuo, R. (2017) Phenotypic and Comparative Transcriptome Analysis of Different Ploidy Plants in Dendrocalamus latiflorus Munro. Frontiers in Plant Science, 8, 1371. https://doi.org/10.3389/fpls.2017.01371

[120] Weiss, H. and Maluszynska, J. (2000) Chromosomal Rearrangement in Autotetraploid Plants of Arabidopsis thaliana. Hereditas, 133, 255-261. https://doi.org/10.1111/j.1601-5223.2000.00255.X

[121] Mena, M., Ambrose, B., Meeley, R., Briggs, S., Yanofsky, M. and Schmidt, R. (1996) Diversification of C-Function Activity in Maize Flower Development. Science, 274, 1537-1540. https://doi.org/10.1126/science.274.5292.1537

[122] Hu, C., Lin, S., Chi, W. and Charng, Y. (2012) Recent Gene Duplication and Subfunctionalization Produced a Mitochondrial GrpE, the Nucleotide Exchange Factor of the Hsp70 Complex, Specialized in Thermotolerance to Chronic Heat Stress in Arabidopsis. Plant Physiology, 158, 747-758. https://doi.org/10.1104/pp.111.187674

[123] D’Amelia, V., Aversano, R., Ruggiero, A., Batelli, G., Appelhagen, I., Dinacci, C., Hill, L., Martin, C. and Carputo, D. (2018) Subfunctionalization of Duplicate $M Y B$ Genes in Solanum commersonii Generated the Cold-Induced ScAN2 and the Anthocyanin Regulator ScAN1. Plant, Cell \& Environment, 41, 1038-1051. https://doi.org/10.1111/pce.12966

[124] Drea, S.C., Lao, N.T., Wolfe, K.H. and Kavanagh, T.A. (2006) Gene Duplication, Exon Gain and Neofunctionalization of OEP16-Related Genes in Land Plants. The Plant Journal, 46, 723-735. https://doi.org/10.1111/j.1365-313X.2006.02741.x

[125] Erdmann, R., Gramzow, L., Melzer, R., Theissen, G. and Becker, A. (2010) GORDITA (AGL63) Is a Young Paralog of the Arabidopsis thaliana $\mathrm{B}_{\text {sister }} M A D S$ Box Gene ABS (TT16) that Has Undergone Neofunctionalization. The Plant Journal, 63, 914-924. https://doi.org/10.1111/j.1365-313X.2010.04290.x

[126] Mollinari, M. and Garcia, A.A.F. (2018) Linkage Analysis and Haplotype Phasing in Experimental Autopolyploid Populations with High Ploidy Level Using Hidden 
Markov Models. BioRxiv, Article ID: 415232. https://doi.org/10.1101/415232

[127] Vicient, C.M. and Casacuberta, J.M. (2017) Impact of Transposable Elements on Polyploid Plant Genomes. Annals of Botany, 120, 195-207. https://doi.org/10.1093/aob/mcx078

[128] Bardil, A., Tayale, A. and Parisod, C. (2015) Evolutionary Dynamics of Retrotransposons Following Autopolyploidy in the Buckler Mustard Species Complex. The Plant Journal, 82, 621-631. https://doi.org/10.1111/tpj.12837

[129] Zhou, K., Fleet, P., Nevo, E., Zhang, X. and Sun, G. (2017) Transcriptome Analysis Reveals Plant Response to Colchicine Treatment during on Chromosome Doubling. Scientific Reports, 7, 8503. https://doi.org/10.1038/s41598-017-08391-2

[130] Ren, R., Wang, H., Guo, C., Zhang, N., Zeng, L., Chen, Y., Ma, H. and Qi, J. (2018) Widespread Whole Genome Duplications Contribute to Genome Complexity and Species Diversity in Angiosperms. Molecular Plant, 11, 414-428. https://doi.org/10.1016/j.molp.2018.01.002

[131] Gout, J. and Lynch, M. (2015) Maintenance and Loss of Duplicated Genes by Dosage Subfunctionalization. Molecular Biology and Evolution, 32, 2141-2148. https://doi.org/10.1093/molbev/msv095

[132] Shi, X., Zhang, C., Ko, D.K. and Chen, Z.J. (2015) Genome-Wide Dosage-Dependent and -Independent Regulation Contributes to Gene Expression and Evolutionary Novelty in Plant Polyploids. Molecular Biology and Evolution, 32, 2351-2366. https://doi.org/10.1093/molbev/msv116

[133] Fan, G., Wang, L., Deng, M., Zhao, Z., Dong, Y., Zhang, X. and Li, Y. (2016) Changes in Transcript Related to Osmosis and Intracellular Ion Homeostasis in Paulownia tomentosa under Salt Stress. Frontiers in Plant Science, 7, 384. https://doi.org/10.3389/fpls.2016.00384

[134] Gavrilenko, T., Thieme, R. and Rokka, V.M. (2001) Cytogenetic Analysis of Lycopersicon Esculentum (+) Solanum etuberosum Somatic Hybrids and Their Androgenetic Regenerants. Theoretical and Applied Genetics, 103, 231-239. https://doi.org/10.1007/s001220100626

[135] Guerra, D., Teresa Schifino Wittmann, M., Schwarz, S., Souza, P., Gonzatto, M. and Weiler, R. (2014) Comparison between Diploid and Tetraploid Citrus Rootstocks: Morphological Characterization and Growth Evaluation. Bragantia, 73, 1-7. https://doi.org/10.1590/brag.2014.007

[136] Tang, Z., Chen, D., Song, Z., He, Y. and Cai, D. (2010) In Vitro Induction and Identification of Tetraploid Plants of Paulownia tomentosa. Plant Cell Tissue and Organ Culture, 102, 213-220. https://doi.org/10.1007/s11240-010-9724-6

[137] Balogh, L. (2008) Sunflower species (Helianthus spp.). Institute of Ecology and Botany, Hungarian Academy of Sciences, Vácrátót, Hungary. 227-255.

[138] Bombarely, A., Rosli, H., Vrebalov, J., Moffett, P., Mueller, L. and Martin, G. (2012) A Draft Genome Sequence of Nicotiana benthamiana to Enhance Molecular Plant-Microbe Biology Research. Molecular Plant-Microbe Interactions, 25, 1523-1530. https://doi.org/10.1094/MPMI-06-12-0148-TA

[139] Fan, G.Q., Cao, Y.C., Zhao, Z.L. and Yang, Z.Q. (2007) Induction of Autotetraploid of Paulownia fortunei. Scientia Silvae Sinicae, 43, 31-35.

[140] Nasr, M., Habib, H.M., Ibrahim, I.A. and Kapiel, T. (2004) In Vitro Induction of Autotetraploid Watermelons Using Colchicine and Four Dinitroaniline Compounds. Proceedings of International Conference of Genetic Engineering and Its Applications, Sharm Elsheik, Egypt, 8-11 April 2004, 1-20. 
[141] Kamm, A., Galasso, I., Schmidt, T. and Heslop-Harrison, J.S. (1995) Analysis of a Repetitive DNA Family from Arabidopsis arenosa and Relationships between Arabidopsis Species. Plant Molecular Biology, 27, 853-862. https://doi.org/10.1007/BF00037014

[142] Albayrak, S., Türk, M., Sevİmay, C.S. and Anakhatoon, E. (2015) Karyotype Characterization of Alfalfa (Medicago sativa L.) Collected from Lake Regions of Turkey. Scientific Papers-Series A, Agronomy, 58, 351-353.

[143] Li, L., Deng, C.H., Knäbel, M., Chagné, D., Kumar, S., Sun, J., Zhang, S. and Wu, J. (2017) Integrated High-Density Consensus Genetic Map of Pyrus and Anchoring of the 'Bartlett' v1.0 (Pyrus communis) Genome. DNA Research, 24, 289-301.

https://doi.org/10.1093/dnares/dsw063 